Note

\title{
Same-Sex Marriage and the Right of Privacy
}

\author{
William M. Hohengarten
}

In 1970 Richard Baker and James McConnell applied for a marriage license in Hennepin County, Minnesota. When the county clerk denied their application because they were both men, the couple went to court. But the trial court upheld the clerk's action, and the state supreme court affirmed. ${ }^{1}$ The Minnesota court ruled that same-sex couples have no legal right to marry because marriage is and always has been an inherently heterosexual institution, "a union of man and woman, uniquely involving the procreation and rearing of children." Other courts have agreed: Same-sex couples are excluded from marriage by the nature of marriage itself. When two Kentucky women claimed a constitutional right to marry, for example, the state's highest court rejected their suit with the observation: "It appears to us that appellants are prevented from marrying, not by the statutes of Kentucky or the refusal of the County Court Clerk of Jefferson County to issue them a license, but rather by their own incapability of entering into a marriage as that term is defined."3

1. Baker v. Nelson, 191 N.W.2d 185 (Minn. 1971), appeal dismissed for lack of substantial federal question, 409 U.S. 810 (1972). Although the Supreme Court's dismissal of Baker has the effect of a decision on the merits, its value as precedent is substantially reduced by the intervening 23 years of privacy precedents, including Zablocki v. Redhail, 434 U.S. 374 (1978) (holding that right to marry is fundamental).

2. Baker, 191 N.W.2d at 186.

3. Jones v. Hallahan, 501 S.W.2d 588, 589 (Ky. 1973). In addition to Jones and Baker, cases holding that same-sex couples do not have a legal right to marry include: Dean v. District of Columbia, No. 9013892 (D.C. Super. Ct. June 2, 1992); Anonymous v. Anonymous, 325 N.Y.S.2d 499 (Sup. Ct. 1971); De Santo v. Barnsley, 476 A.2d 952 (Pa. Super. Ct. 1984); Singer v. Hara, 522 P.2d 1187 (Wash. Ct. App.), review denied, 84 Wash. 2d 1008 (1974); see also Adams v. Howerton, 486 F. Supp. 1119 (C.D. Cal. 1980) (holding that even if same-sex marriage were valid under state law, such marriage would not confer spouse status under federal Immigration and Nationality Act), aff'd, 673 F.2d 1036 (9th Cir.), cert. denied, 
This Note argues that these courts are wrong: The constitutional right of privacy requires states to sanction and recognize same-sex marriages. ${ }^{4}$ There is nothing intrinsic to the legal institution of marriage that excludes same-sex couples from it. Viewed functionally, legal marriage is essentially a binding commitment uniting two intimately related adults, a commitment which sustains the relationship between such adults by structuring their dealings with each other and with third parties. Conceived in this way, marriage is indifferent to the relative genders of its occupants. And because marriage is not intrinsically closed to same-sex couples, the fundamental right to marry-which is a core element of the constitutional right of privacy-also extends to such couples. ${ }^{5}$

The right to marry is not entirely unproblematic. It differs from other rights protected under the rubric of "privacy," such as procreation, abortion, or child rearing, because marriage is not something that exists apart from the law or the state. Marriage is a legal relationship, entered into through a legal framework, and enforceable according to legal rules. Law stands at its very core. Due to this inherent "legalness" of marriage, the constitutional right to marry cannot be secured simply by removing legal barriers to something that exists outside of the law. Rather, the law itself must create the "thing" to which one has a right. As a result, the right to marry necessarily imposes an affirmative obligation on the state to establish this legal framework.

The legalness of marriage also gives rise to the definitional difficulties that surfaced when Richard Baker and James McConnell first sought a marriage license in Minnesota. The disagreement between the couple and the state about whether the fundamental right to marry extends to same-sex couples reflected a more profound disagreement about what marriage is. Resolving this deeper

458 U.S. 1111 (1982). The first and, as yet, only American case to have ruled in favor of a challenge to a prohibition of same-sex marriage is Baehr v. Lewin, 852 P.2d 44 (Haw. 1993), in which the Hawaii Supreme Court held that the state's prohibition on same-sex marriage employs a facial gender classification subject to strict scrutiny under the Hawaii Constitution's equal protection provision and equal rights amendment. Id. at 64-67. The court remanded for a consideration of any compelling state interests that might justify the gender classification. Baehr also ruled, however, that same-sex couples, unlike oppositesex couples, do not have a fundamental right to marry. Id. at 57. For further discussion of Baehr, see infra note 8 and notes 53-54 and accompanying text.

4. More precisely, the right of privacy requires states to recognize same-sex marriages unless there are countervailing state interests that are sufficiently weighty to satisfy an "intermediate" level of constitutional scrutiny. See infra note 46 . This Note argues that same-sex couples have a fundamental right to marry, but it does not consider whether there are countervailing state interests that might outweigh that right.

5. This claim may at first appear to conflict with Bowers v. Hardwick, 478 U.S. 186 (1986), which held that the right of privacy does not prevent states from criminalizing sexual conduct involving same-sex couples. However, as Part IV of this Note demonstrates, the fundamental right to marry does not depend on an anterior right to engage in sexual conduct outside of marriage. See infra notes 115-29 and accompanying text. The primary concern of the right of privacy is not sexual conduct, but the formation of families: The state may not interfere with basic familial decisions, including decisions relating to marriage. Quite simply, the right to marry is fundamental. E.g., Zablocki v. Redhail, 434 U.S. 374, 384 (1978); see also infra Part II. As a result, this right may not be infringed simply because the state has an otherwise legitimate interest in regulating sexual conduct. 
disagreement poses special difficulties. Since marriage is a legal relationship, its definition cannot be derived from something that exists outside of the law. At the same time, existing legal definitions of marriage cannot be accepted as self-validating, as a positivistic view of law might otherwise suggest, because the fundamental right to marry prohibits states from defining marriage in ways that unduly exclude some couples from it. ${ }^{6}$ On the surface, then, it appears that neither the law nor anything outside the law can provide a dispositive definition of marriage.

This Note attempts to dissolve this dilemma by taking a holistic approach to the law governing marriage. Such an approach does not look outside the law for a definition of marriage, but it also does not accept specific legal exclusions from marriage at face value. Rather, it tests specific exclusions by asking whether they are connected to the functions of marriage as these are reflected in the law as a whole. ${ }^{7}$ This Note develops its understanding of marriage by moving between analyses of the state law of domestic relations and analyses of the constitutional law of privacy. The primary objective is to derive an interpretation of legal marriage against which the exclusion of samesex couples can be tested. A secondary goal is to use the resulting understanding of marriage to illuminate the constitutional right of privacy, and thus to clarify how marriage furthers the liberty interests of the couple by imposing an affirmative obligation on the state. ${ }^{8}$

6. See infra Part II.A.; see also Mark Strasser, Family, Definitions, and the Constitution, 25 SuFroLK U. L. REV. 981, 982-89 (1991) (arguing that legislatures may not circumvent constitutional limits on regulation of marriage simply by stipulating preferred definition of marriage).

7. To an earlier generation of Legal Realists, this mode of inquiry might have seemed like "transcendental nonsense," or the variety of confusion that results when courts treat legal categories as things whose essential properties can be read off from them. Such arguments appear to move in a circle because their legal conclusions simply reflect the way in which the law has defined these legal "things." See Felix S. Cohen, Transcendental Nonsense and the Functional Approach, 35 CoLUM. L. REv. 809, 813, passim (1935). Same-sex marriage cases frequently engage in precisely this type of "tautological jurisprudence" when they reify the state's own legal definition of marriage in order to validate that very definition. See Nan D. Hunter, Marriage, Law, and Gender: A Feminist Inquiry, 1 LAW \& Sexualty 9, 13-14 (1991). Yet the apparent circularity of much legal reasoning need not be fatal tautology. Instead, it may be an instance of the "hermeneutic circle" that is intrinsic in every interpretive endeavor as it shuttles between anticipatory interpretations of a complete text and detailed readings of its parts. See HANS-GEORG GADAMER, TRUTH AND METHOD 235-37 (Crossroad Publ. Co. 1975) (1965). Such a hermeneutic circle is implicit in the holistic approach that this Note takes to the law.

8. This Note does not address a closely related issue: whether the prohibition of same-sex marriage employs a (quasi-)suspect classification and thereby violates the constitutional guarantee of equal protection. As the Hawaii Supreme Court recently demonstrated in Baehr v. Lewin, 852 P.2d 44 (Haw. 1993), this equal protection question can be answered without any inquiry into the nature of marriage itself, because the prohibition of same-sex marriage employs a facial classification based on the relative genders of the parties. In view of this gender classification, Baehr held that the state's prohibition of same-sex marriage is subject to strict scrutiny under the Hawaii Constitution. Id. at 64, 67, 74-75 (remanding for consideration of any compelling state interest that might justify classification). The use of a facial gender classification should require heightened scrutiny even when (as Baehr also held) same-sex couples do not have a fundamental right to marry. Id. at 55-57; see also infra notes 53-54 and accompanying text.

Other courts have rejected equal protection challenges to the prohibition of same-sex marriage. It is not always clear, however, whether these courts hold that this marriage prohibition does not employ a gender classification at all, or whether they hold that the use of such a gender classification does not require heightened scrutiny because marriage is (allegedly) an inherently gendered institution. See, e.g., Baker v. 
The argument proceeds in four stages. Part I develops a provisional definition of legal marriage by inquiring into the functions it uniquely serves. From this functional perspective, marriage appears simply as a legal framework for a committed relationship between two adults, without regard to their genders. Part $I I$ examines the case law surrounding the constitutional right to marry and presents the courts' alternative interpretation of marriage, which centers on procreation and is thought inherently to exclude same-sex couples. Part III criticizes this procreative interpretation of marriage as unsupported by state domestic relations law. Finally, Part IV argues that linking the right to marry with procreation is also inconsistent with the broader constitutional right of privacy. There is therefore no basis for limiting the fundamental right to marry to opposite-sex couples.

\section{Why MarRiage? The Function of a Legal Status}

One way to approach the problem of defining legal marriage is to ask what functions it serves that other legal institutions do not. This Part pursues this inquiry by focusing on what same-sex couples would gain if their right to marry were legally recognized. The answer that emerges is that marriage provides a legal framework for a committed relationship between two adults, a framework that cannot be duplicated by other legal forms. ${ }^{9}$

Discussions of same-sex marriage frequently focus on the issue of "benefits," that is, on the pecuniary advantages that third parties sometimes bestow on married couples. ${ }^{10}$ Logically, however, an analysis of marriage

Nelson, 191 N.W.2d 185, 187 (Minn. 1971), appeal dismissed, 409 U.S. 810 (1972); Singer v. Hara, 522 P.2d 1187, 1191-92 (Wash. Ct. App.), review denied, 84 Wash. 2d 1008 (1974).

An extensive academic literature analyzes the prohibition of same-sex marriage in equal protection terms. Particularly noteworthy are Note, The Legality of Homosexual Marriage, 82 YALE L.J. 573 (1973) (arguing that prohibitions of same-sex marriage would violate anticipated federal Equal Rights Amendment); Comment, Homosexuals' Right To Marry, 128 U. PA. L. REV. 193 (1979) (undertaking equal protection analysis based on sexual orientation); Andrew Koppelman, Note, The Miscegenation Analogy: Sodomy Law as Sex Discrimination, 98 YALE L.J. 145, 147 (1988) (arguing that sodomy laws that are targeted specifically against same-sex couples, like antimiscegenation laws, violate equal protection by maintaining caste regime locking some people into inferior racial or gender roles at birth); Hunter, supra note 7, at 14-17 (extending Koppelman-type argument to prohibitions of same-sex marriage); James Trosino, Note, American Wedding: Same-Sex Marriage and the Miscegenation Analogy, 73 B.U. L. REv. 93 (1993) (same).

9. Parts II through IV, infra, confirm this functional reading by testing it against other aspects of the law relating to marriage.

10. See, e.g., Paula Ettelbrick, Since When Is Marriage a Path to Liberation?, in LeSBIANS, GAY MEN, AND THE LAW 404, 405 (William B. Rubenstein ed., 1993) (arguing that economic benefits unfairly privilege marriage and that same-sex couples should therefore not seek right to marry); Rhonda R. Rivera, Queer Law: Sexual Orientation Law in the Mid-Eighties, 11 U. DAYTON L. REv. 275, 325 (1986) (stating that most same-sex couples seek equal economic benefits for their relationships, rather than marriage); Thomas Stoddard, Why Gay People Should Seek the Right To Marny, in LESBIANS, GAY MEN, AND THE LAW, supra, at 398, 399 (arguing that same-sex couples should seek right to marry in part to get economic benefits); Developments in the Law-Sexual Orientation and the Law, I02 HARV. L. REV. 1508, 1604 (1989) (listing economic benefits denied as consequence of nonrecognition of same-sex marriages). Stoddard lists several benefits of marriage that are supplied by the government (e.g., potentially reduced 
should begin by examining the legal relationship that unites the two individuals who marry one another, not their relationships with third parties. When two individuals marry, they enter into a legally binding relationship with each other. This relationship is binding because the state imposes significant conditions on exiting it; a spouse cannot simply walk away from marriage. ${ }^{11}$ Marriage thus offers a legal medium through which two adults can make a mutual commitment to stay together. This mutual commitment functions as a relatively stable basis upon which they can structure aspects of their life together and their joint interactions with third parties. In short, marriage allows a couple to overcome the deep-seated individualism of contemporary life and to operate, for many purposes, as a unit. ${ }^{12}$

On this reading, marriage is an enabling constraint which resembles contract. Like contract, marriage can only be entered by the mutual consent of the parties. Yet marriage has usually been treated as a status, not a contract, because its terms have traditionally been set by the state and have not been renegotiable by the parties. ${ }^{13}$ Although in recent years contract has come to provide a significant alternative to marital status for governing the reciprocal economic relations of couples, marriage remains a status-based relation inasmuch as the state continues to regulate the conditions under which a couple may terminate its relationship. It is in this latter respect that the status of marriage provides a unique legal resource for structuring intimate relationships, a resource whose function cannot be duplicated by other legal media.

Until recently, marital property rights were defined exclusively by the state. Married couples could not use prenuptial agreements to negotiate their mutual property rights in case of divorce, because such agreements were generally held void as collusive attempts to obtain a divorce. ${ }^{14}$ Similarly,

tax liability, certain Social Security benefits, rights of intestate succession, and rights of foreign spouses to reside in the United States) and others that are customarily supplied by private parties such as employers (e.g., medical benefits for spouses). Stoddard, supra, at 399.

11. See infra notes 19-24 and accompanying text.

12. This conception of marriage is related to that advocated in Kenneth $\mathrm{L}$. Karst, The Freedom of Intimate Association, 89 YALE L.J. 624 (1980). Karst argues that marriage is important for a same-sex couple's freedom of intimate association because it is "a formalized legal status that recognizes their union and commitment." Id. at 684. Karst sees the value of this legal status primarily in symbolic terms, as a medium through which the couple can express their personal commitment in a socially acceptable manner. In contrast, this Note lays greater stress on the fact that marriage can provide a stable legal basis for a couple's relationship by allowing them to make a legally binding commitment to each other. Advocates of same-sex marriage have probably played down this legally binding aspect of marriage because the battle against criminal sanctions on same-sex sexual activity has entrenched a general hostility in the gay and lesbian community to state "interference" in intimate relationships. Cf. William B. Rubenstein, The Regulation of Lesbian and Gay Sexuality, in LESBIANS, GAY MEN, AND THE LAW, supra note 10, at 77, 77 (stating that existence of criminal sodomy laws has been used to "justify" general discrimination against gays and lesbians). This Note argues that the state exercises unwarranted control over intimate relationships not only through the application of criminal sanctions, but also by denying access to certain legal institutions, including marriage.

13. See, e.g., Maynard v. Hill, 125 U.S. 190, 211 (1888); Adams v. Palmer, 51 Me. 480, 483 (1863); JOSEPH STORY, CONFLICT OF LAWS $\$ 108$ (Boston, Little \& Brown, 3d ed. 1846).

14. See Posner v. Posner, 233 So. 2d 381, 382-83 (Fla. 1970). 
unmarried couples could not use contract to mimic the state's marital property regime, because such contracts were held to be based upon "meretricious" sexual consideration and thus also void. ${ }^{15}$ In short, married couples were not free to opt out of the state's marital property regime, and unmarried couples were not free to opt into it. Since the 1970's, however, this bifurcated system has lost much of its rigidity because contract has largely supplanted status as a legal basis for the regulation of the mutual property rights of couples. Prenuptial agreements are now typically upheld when they regulate the property settlement for a divorce prosecuted upon legally recognized grounds. ${ }^{16}$ Contracts governing property relations between unmarried cohabitants are also generally upheld if they are not expressly founded on the consideration of meretricious services. ${ }^{17}$ Thus, most states now set mere default rules governing the mutual property rights of both married and unmarried couples. ${ }^{18}$ This trend has reduced the differences between married and unmarried couples with regard to their mutual property rights, since couples in either category may usually rearrange these rights by mutual consent. As a result, contract now provides a functional alternative to marriage as a medium for regulating the economic aspect of a couple's relationship.

The same cannot be said of the conditions under which a couple may legally terminate its relationship. While prenuptial agreements and cohabitation contracts can alter the default rules governing the distribution of property upon dissolution of a relationship, they cannot alter the conditions under which such dissolution may take place. As before, prenuptial contracts are void if they represent a collusive effort to procure a divorce when legally recognized

15. See Hewitt v. Hewitt, 394 N.E.2d 1204, 1208 (Ill. 1979); Marvin v. Marvin, 557 P.2d 106, 112 (Cal. 1976).

16. Posner v. Posner, 233 So. $2 \mathrm{~d}$ at 385-86; Osborne v. Osborne, 428 N.E.2d 810, 815-16 (Mass. 1981). Similarly, probate laws now generally allow the contractual waiver of a surviving spouse's default rights, such as the right to an elective share, in a decedent spouse's estate. See, e.g., UNIF. PROBATE CODE $\S 2-204$ (a) (1990).

17. Marvin v. Marvin, 557 P.2d at 110 .

18. Note that this movement from status to contract is a matter of optional state policy; as such, it is not without exceptions. For limits on prenuptial agreements, see, e.g., Posner v. Posner, 233 So. $2 \mathrm{~d}$ at 386 (making prenuptial agreements subject to modification upon change of conditions); Lutgert v. Lutgert, 338 So. 2d 1111, 1116-17 (Fla. Dist. Ct. App. 1976) (voiding prenuptial agreement for involuntariness); In $r e$ Estate of Benker, 331 N.W.2d 193, 201 (Mich. 1982) (voiding prenuptial agreement for nondisclosure of husband's financial situation, and creating rebuttable presumption of such nondisclosure under certain circumstances); UNIF. PREMARITAL AGREEMENT ACT \$ 6, 9B U.L.A. 376 (1983) (voiding premarital agreements that are involuntary or unconscionable and based on ignorance of one party's financial situation); UNIF. PROBATE CODE \$ 2-204(b) (1990) (voiding waiver of spousal rights in decedent's estate if involuntary or if unconscionable and based on inadequate information). For limits on contracts mimicking marital property rights by unmarried cohabitants, see, e.g., Hewitt v. Hewitt, 394 N.E.2d at 1211 (holding unenforceable Marvin-type contract claims based on intimate relationship as contrary to state's policy requiring solemnization of marriage). Contractual regimes governing marital property rights have also been criticized for enforcing agreements between parties who often possess unequal bargaining power or who do not negotiate at arms length. See, e.g., Grace G. Blumberg, Cohabitation Without Marriage, 28 UCLA L. REV. 1125, 1159-70 (1981) (criticizing trend toward resolving unmarried cohabitants' inter se property rights on basis of parties' intent). 
grounds are lacking. ${ }^{19}$ The parties to a marriage may not lower the hurdles that the state places before a divorce. But the parties cannot raise these hurdles, either. A corollary of the status theory of marriage is that the state has the exclusive prerogative to define the grounds for its dissolution. Thus, states may lower the hurdles to dissolution after a marriage has been celebrated and grant a divorce under the lowered standard even when one spouse objects. ${ }^{20}$ Like the marital property agreements of old, an agreement between the spouses to abide by their own standards for divorce is still legally unenforceable today.

Just as married couples may not opt out of the state regime for granting divorces, unmarried couples may not opt into it. ${ }^{21}$ If divorce is understood as permission to remarry, then unmarried parties cannot divorce, since they do not need permission to (re)marry in the first place. Like married couples, unmarried couples may not contract for more stringent dissolution requirements than those mandated by the state. ${ }^{22} \mathrm{~A}$ member of an unmarried couple is legally free to walk away from the relationship and marry someone else. Thus, although unmarried couples may enter into an enforceable contract governing their reciprocal property rights, they may not enter into an enforceable commitment to remain together.

In sum, marriage is the only medium whereby two individuals can make a legally enforceable commitment to remain together. To be sure, the legal hurdle to divorce is no longer so high that a party who is dissatisfied with a marriage cannot eventually dissolve it. ${ }^{23}$ In late twentieth-century America, marriage does not operate as a guarantee that the couple will stay together. Nonetheless, because the procedural costs of exiting a marriage are substantially higher than the (nonexistent) procedural costs of exiting a nonmarital relationship, marriage does provide a relatively stable legal basis for a committed relationship. The fact that marriage involves a legally

19. E.g., Posner v. Posner, 233 So. 2 d at 385.

20. In re Marriage of Walton, 104 Cal. Rptr. 472, $475-77$ (Ct. App. 1972) (holding that spouse can have no vested interest in grounds for divorce existing at time of marriage); Adams v. Palmer, 51 Me. 480 , 482-84 (1863) (holding that state does not impair validity of contracts by granting legislative divorce); Buchholz v. Buchholz, 248 N.W.2d 21, 23 (Neb. 1976) (holding that marriage is not protected property interest but is subject to dissolution on terms chosen by state); Williams v. Williams, 543 P.2d 1401, 140304 (Okla.) (holding that state has absolute power to prescribe conditions of divorce notwithstanding any stricter vows made by parties in accordance with their religious beliefs), cert. denied and appeal disnissed, 426 U.S. 901 (1976).

21. See De Santo v. Barnsley, 476 A.2d 952, $955-56$ (Pa. Super. Ct. 1984) (holding same-sex partner's petition for divorce properly dismissed because two persons of same-sex cannot contract (common-law) marriage).

22. Any agreement by an unmarried couple to dissolve its relationship only under certain specified circumstances could, if enforced, prevent each of them from marrying someone else. Such an agreement would probably be unenforceable as a restraint on marriage. See RESTATEMENT (SECOND) OF CONTRACTS $\S 189$ (1979) ("A promise is unenforceable on grounds of public policy if it is unreasonably in restraint of marriage.").

23. See infra notes $70-75$ and accompanying text (discussing no-fault divorce regimes). 
enforceable commitment differentiates it fundamentally from alternative forms of public "commitment" ceremonies or private vows. ${ }^{24}$

The genius of marriage is that it allows a couple to come together as a unit $^{25}$-if the couple so chooses. Persons who wish to maintain and emphasize their absolute legal individuality are free not to marry, even if they are involved in a profound and satisfying intimate relationship. This option throws light on the economic "benefits" that third parties sometimes bestow on married couples. Some lesbian and gay activists criticize the idea of marriage generally, and same-sex marriage in particular, because they believe that third-party economic benefits privilege marital relationships over alternative forms of familial life. ${ }^{26}$ Yet, the differential treatment that married partners often receive may not privilege marriage at all; rather, such treatment may simply reflect the fact that married couples have chosen to operate as a unit while unmarried persons have not. In that case, marriage would simply provide an administrable criterion for tailoring benefit programs to the family structures that different beneficiaries have chosen.

A realistic view of the package of "benefits" received by married couples supports this conception. Gay and lesbian advocates of same-sex marriage have understandably focused on those benefits of marriage from which they are excluded, and gay and lesbian critics have followed suit by objecting to the way such benefits apparently privilege marriage. The result, however, is that the burdens associated with marriage are usually ignored. For example, the oftcited "benefit" of filing a joint tax return turns out, on closer inspection, frequently to be a burden-the well-known "marriage penalty," under which many married couples pay more tax than unmarried couples with the same joint income. ${ }^{27}$ The double-edged quality for married couples of this tax provision is mirrored by others in the Internal Revenue Code, such as those relating to wealth transfers between spouses (gain is not recognized, but neither is loss) ${ }^{28}$ The policy behind these Code provisions is not to privilege married

24. It is precisely this mutually binding aspect of marriage that is missing from the "domestic partnerships" now recognized in some local jurisdictions. See infra note 36.

25. The use of the term "unit" is not intended to imply that the parties to a marriage lose their separate identities or that they become a single legal person-marriage no longer merges the legal identity of one partner (the wife) into that of the other (the husband). Unlike most other types of mutual commitment recognized by our legal system, however, marriage is not merely based upon the transient economic selfinterest of monadic individuals. Rather, marriage is a legal medium whereby two individuals can commit themselves to joining together as a unit in pursuing a common life project.

26. See, e.g., Ettelbrick, supra note 10 , at 405 .

27. The "marriage penalty" results when the couple consists not of one wage earner and one non-wage earner, but of two wage earners whose separate incomes are roughly similar. Patricia A. Cain, Same-Sex Couples and the Federal Tax Laws, 1 LAW \& SEXUALITY 97, 98 (1991). Compare I.R.C. $\$$ I(a), (d) (West Supp. 1993) (setting income tax rates for married persons filing joint returns and for married persons filing separately) with I.R.C. \$ 1(c) (West Supp. 1993) (setting income tax rates for unmarried persons).

28. See Cain, supra note 27 , at $98-99$ (listing tax-related benefits and burdens applicable only to married couples); see also Nitya Duclos, Some Complicating Thoughts on Same-Sex Marriage, 1 LAW \& SEXUALITY 31, 52-54 (1991) (listing non-tax-related benefits and burdens associated with marriage). 
couples, but to arrive at a realistic "tax unit" when a couple, rather than an individual, operates as an economic unit. ${ }^{29}$

Marriage bundles benefits with burdens. When married couples and unmarried individuals receive differential treatment, it should ideally reflect the differences in their circumstances. Because most married couples pool their resources in a single household, it makes sense for the state to treat them as a single economic unit when evaluating their entitlements and liabilities under programs based on financial need or ability to pay. In the context of a mobile society with an unstable labor market, it may also make sense to extend jobrelated benefits, such as health insurance and pensions, to the spouses of employees, since these spouses might have sacrificed their own direct access to such benefits in order to keep a mobile household intact. Such spousal benefits do not necessarily represent undeserved windfalls-unless one assumes that the norm for measuring the fairness of all systems of compensation is the individual who maximizes his or her own earnings and benefits without regard to long-term personal commitments.

Critics of marriage have objected that under this approach to third-party benefits, state and private recognition of intimate relationships turns on "a simple certificate of the state," rather than on the actual "relationship among people." ${ }^{130}$ In fact, real state intrusion occurs when legally recognized forms for indicating family status are absent, not when they are available. The problems become apparent in the celebrated case of Braschi v. Stahl Associates, ${ }^{31}$ in which the term "family," used in New York regulations to describe persons who cannot be evicted from a rent-controlled apartment when the leaseholder dies, was construed to include "two adult lifetime partners whose relationship is long term and characterized by an emotional and financial commitment and interdependence." ${ }^{32}$ Because the lifetime partners involved in Braschi were both men, they could not enter into a legal marriage with each other. Given the absence of legally recognized forms for indicating family status in this context, the court was no doubt correct to reject the requirement of a marriage license as placing "fictitious legal distinctions" before "the reality of family life." ${ }^{\text {"33 }}$ Nonetheless, when courts delve directly into the "reality" of family life, it places heavy burdens not only on the judiciary, but also on the family subjected to its scrutiny. Consider the inquiry suggested in Braschi:

The determination as to whether an individual is entitled to noneviction protection should be based upon an objective examination

\footnotetext{
29. See Cain, supra note 27 , at 129.

30. See, e.g., Ettelbrick, supra note 10, at 404-05.

31. 543 N.E.2d 49 (N.Y. 1989).

32. Id. at 54 .

33. Id. at 53 .
} 
of the relationship of the parties. In making this assessment, the lower courts of this State have looked to a number of factors, including the exclusivity and longevity of the relationship, the level of emotional and financial commitment, the manner in which the parties have conducted their everyday lives and held themselves out to society, and the reliance placed upon one another for daily family services. These factors are most helpful, although it should be emphasized that the presence or absence of one or more of them is not dispositive since it is the totality of the relationship as evidenced by the dedication, caring and self-sacrifice of the parties which should, in the final analysis, control. ${ }^{34}$

It is little wonder that other courts in other circumstances have found this inquiry to be beyond their institutional competence. ${ }^{35}$ Bureaucratic state institutions can assess the formalities of family life better than the realities, especially when the realities take nontraditional forms. Unfairness develops only when such formalities are denied to particular groups-such as same-sex couples. $^{36}$

34. Id. at 55 (citations omitted); cf. Blumberg, supra note 18, at 1127, 1131 (proposing, in context of opposite-sex couples, a legally recognized state of "cohabitation" based on "objective criteria" similar to those in Braschi, adding that "[w]hich elements should be used to define unmarried cohabitation depends on which are salient to the particular legal context in which the issue arises"); Ellen Kandoian, Cohabitation, Common Law Marriage, and the Possibility of a Shared Moral Life, 75 GEo. L.J. 1829, 1870 (1987) (proposing definition of de facto marriage, modeled on law of business partnerships, as "association of two persons to carry on a shared life").

35. See, for example, Elden v. Sheldon, 758 P.2d 582 (Cal. 1988), which denied a claim for negligent infliction of emotional distress to a plaintiff who witnessed his unmarried opposite-sex partner's death, because the allowance of such claims "would impose a difficult burden on the courts. It would require a court to inquire into the relationship of the partners to determine whether the "emotional attachments of the family relationship' existed between the parties, and whether the relationship was 'stable and significant."' Id. at 587 (citations omitted); see also Coon v. Joseph, 237 Cal. Rptr. 873 (Ct. App. 1987) (denying recovery for negligent infliction of emotional distress to same-sex partner because couple was not legally married). See generally Note, Looking for a Family Resemblance: The Limits of the Functional Approach to the Legal Definition of Family, 104 HARV. L. REV. 1640 (1991). Private institutions, such as insurance companies, also may resist the institutional burdens involved in identifying "functional families." See, e.g., State Farm Mut. Auto Ins. Co. v. Pizzi, 505 A.2d 160, 161-62 (N.J. Super. Ct. App. Div. 1986).

36. To be sure, the state could-and should-recognize alternative formalities, such as "domestic partnership" registration, that enable a couple to indicate its preference for being treated as a unit for some purposes without any other state regulation of its relationship. Like marriage, domestic partnership ordinances allow two adults to register as a couple with a governmental body. They differ from marriage primarily in that they do not regulate the partners' reciprocal property rights and that they allow either partner to terminate the domestic partnership at will. See, e.g., San Francisco, Cal., Domestic Partnership Ordinance $\$ 4$ (Jan. 15, 1991), reprinted in LESBIANS, GAY MEN, AND THE LAW, supra note 10, at 439-43 (ordaining that domestic partnership be unilaterally terminable by either partner via death, marriage, or notice to other partner). Thus, a registered domestic partnership allows a couple to define the boundaries of its relationship without the state-imposed terms of marriage. Hunter, supra note 7, at 23-25. These considerations appear to explain why a critic of same-sex marriage such as Paula Ettelbrick endorses the domestic partnership movement. See Ettelbrick, supra note 10, at 405.

Because of problems of opportunism, however, domestic partnership can never completely replace marriage as a criterion for administering programs that are differentially tailored to couples and individuals. Differential treatment creates space for opportunism by couples posing as noncouples and by noncouples posing as couples. For example, the policy of sometimes treating a couple, rather than its separate members, as the appropriate unit for taxation would be undermined if a couple could pick and choose among the marriage-related provisions of the tax code it wished to have applied to it or could choose married or 
In sum, marriage provides a unique legal medium through which intimately related adults can, if they choose, make a binding commitment to each other to act as a unit for many purposes. The partners can rely on this commitment in their dealings with each other, and third parties can rely on it in their dealings with both. Marriage is thus a crucial framework for overcoming the atomistic individualism that pervades our social and legal order. This function of marriage has nothing to do with gender. ${ }^{37}$ It is equally relevant to couples of the same and of the opposite sex. Yet courts that have considered the issue have held that the fundamental right to marry is reserved only to unions of one man and one woman. ${ }^{38}$ What is the rationale behind the courts' gendered conception of this fundamental right?

\section{THE Fundamental Right TO MARRY}

The Supreme Court has long recognized that marriage is a legal construct, a status defined exclusively by the state (although entered only by consent of the parties). ${ }^{39}$ The Court has also held, however, that the states do not possess a free hand in limiting access to marriage, because the right to marry is a constitutionally guaranteed fundamental right. There is an obvious tension between the states' power to define marriage and their obligation not to interfere substantially with decisions to enter into a marital relationship. A resolution of this tension requires a conception of what marriage is and why it is constitutionally protected. Part I sketched a provisional answer to these questions in terms that are indifferent to the relative genders of the couple. This Part reviews the Supreme Court's major decisions concerning the right to marry and then lays out the reasons that other courts have offered for treating this right as necessarily limited to opposite-sex couples.

unmarried tax status on the annual advice of its accountant. The state has a legitimate interest in an administrable test for distinguishing couples from individuals, a test that is not too easy to evade by opportunistically switching statuses whenever profitable. Because exiting (and thus entering) marriage involves costs that are not insignificant, marital status provides such a test, whereas domestic partnership status does not.

37. Of course, this function of marriage may have something to do with "procreation" insofar as couples who wish to raise children will usually choose to marry in order to provide a stable basis for their familial relationship. This connection between marriage and procreation is, however, entirely unlike that asserted by some courts when they contend that the fundamental right to marry does not extend to same-sex couples. See infra Part III.B.

38. See supra note 3.

39. Maynard v. Hill, 125 U.S. 190 (1888) (upholding legislative divorce granted ex parte). The Maynard Court quoted an earlier state case with approval:

"When the contracting parties have entered into the married state, they have not so much entered into a contract as into a new relation, the rights, duties, and obligations of which rest not upon their agreement, but upon the general law of the State, statutory or common, which defines and prescribes those rights, duties, and obligations. ... The reciprocal rights arising from this relation, so long as it continues, are such as the law determines from time to time, and none other."

Id. at 211 (quoting, with changes in punctuation, Adams v. Palmer, 51 Me. 480, 483 (1863)). 


\section{A. Defining Marriage Versus Prohibiting Marriage}

The Supreme Court first held a state statute unconstitutional because it infringed the fundamental right to marry in Loving $v$. Virginia ${ }^{40}$ which struck down Virginia's antimiscegenation statute. Loving is probably best known for the large portion of the decision that is based on the Equal Protection Clause. Yet the Court also rejected the Virginia law because it impermissibly infringed the Lovings' fundamental right to marry. ${ }^{41}$ The brevity of Loving's fundamental rights analysis left much about the scope and weight of the right to marry undecided. It is significant, however, that mixed-race marriages, particularly between blacks and whites, had long been legally forbidden and culturally vilified throughout almost the entire nation. ${ }^{42}$ Considered against this background, Loving represents an unmistakable principle that is relevant to same-sex marriage: The right to marry is not circumscribed by longstanding legal or cultural exclusions from marriage, no matter how deeply rooted in the nation's traditions and history.

The tensions inherent in the idea of a fundamental right to marry played a larger role in the next major marriage decision of the Court, Zablocki $v$. Redhail. $^{43}$ At issue in Zablocki was a Wisconsin statute that prevented indigent persons from marrying if they could not meet their preexisting child support obligations. ${ }^{44}$ The Zablocki Court emphatically reaffirmed Loving's holding that the right to marry is fundamental, and it classified this fundamental right as an aspect of the constitutional right of privacy. ${ }^{45}$ Because the Wisconsin statute directly and substantially interfered with the fundamental right to marry, and because none of the state's proffered

40. 388 U.S. 1 (1967).

41. Id. at 12. In Baker v. Nelson, 191 N.W.2d 185 (Minn. 1971), appeal dismissed, 409 U.S. 810 (1972), the court sought to reduce Loving's fundamental rights holding to a replay of its equal protection holding: "Virginia's antimiscegenation statute, prohibiting interracial marriages, was invalidated solely on the grounds of its patent racial discrimination." Id. at 187. But this reading of Loving is plainly wrong. The second part of Loving mentions the state's use of a racial classification only as a potential justification for limiting the fundamental right to marry, a justification which was then rejected as inadequate to save the statute: "Marriage is one of the "basic civil rights of man' .... To deny this fundamental freedom on so unsupportable a basis as the racial classifications embodied in these statutes ... is surely to deprive all the State's citizens of liberty without due process of law." Loving, 388 U.S. at 12.

42. The first antimiscegenation law in the colonies was enacted in Virginia in 1691 and thus antedated the Constitution by almost a century. Thirty-one states still had such laws at the end of World War II; sixteen states still had them in 1966, shortly before Loving was decided. See Trosino, supra note 8, at 9798. In the Dred Scott decision, Chief Justice Taney cited the antimiscegenation laws of several states, including Massachusetts, Connecticut, New Hampshire, and Rhode Island, as evidence that blacks could not be citizens of the United States; such laws represented the fact that "intermarriages between white persons and negroes or mulattoes were regarded as unnatural and immoral, and punished as crimes, not only in the parties, but in the person who joined them in marriage." Scott v. Sandford, 60 U.S. (19 How.) $393,409,413-16$ (1857).

43. 434 U.S. 374 (1978).

44. Id. at 387.

45. Id. at 384 . 
justifications for this interference could meet the level of heightened scrutiny imposed by the Court, the statute was struck down. ${ }^{46}$

In reaching this result, the Court sought to distinguish between laws through which the state interferes with the decision to marry and laws through which the state simply exercises its traditional power to define the legal incidents of marriage:

By reaffirming the fundamental character of the right to marry, we do not mean to suggest that every state regulation which relates in any way to the incidents of or prerequisites for marriage must be subjected to rigorous scrutiny. To the contrary, reasonable regulations that do not significantly interfere with decisions to enter into the marital relationship may legitimately be imposed. ${ }^{47}$

Under Zablocki, the state's power to define the legal relationship of marriage does not encompass the power to exclude persons from it. ${ }^{48}$ If same-sex couples do have a fundamental right to marry, the state may not negate that right simply by defining marriage as a union between two persons of opposite sexes, just as it could not defeat the fundamental right of mixed-race couples to marry simply by defining marriage as a union of two persons of the same race. Nonetheless, the scope of the fundamental right to marry cannot be completely divorced from how marriage is defined-from what marriage is-for the simple reason that this right is not implicated by prohibitions on relationships that cannot meaningfully be called "marriages" in the first place. ${ }^{49}$ The fact that the state does not recognize same-sex marriages would

46. Under the standard used by the Court, a statute that substantially interferes with the decision to marry "cannot be upheld unless it is supported by sufficiently important state interests and is closely tailored to effectuate only those interests." Id. at 388. This Note does not consider the question whether there may in fact be any state interests that might meet this level of scrutiny and thereby save the constitutionality of prohibitions of same-sex marriage. Rather, it simply argues that the fundamental right to marry does extend to same-sex couples, and that such prohibitions must therefore meet the heightened level of scrutiny advanced in Zablocki.

47. Id. at 386.

48. The need to draw the distinction between defining marriage and excluding persons from it may explain why Justice Marshall's majority opinion overlays its relatively straightforward fundamental rights approach with a veneer of equal protection analysis: It construes the statute as defining a class of persons who have outstanding child support obligations and then subjects this classification to heightened scrutiny under the Equal Protection Clause because it interferes with the exercise of a fundamental right. Id. at 37577,388 . It is clear that it is the statute's interference with the fundamental right to marry that is driving Justice Marshall's analysis; absent this fundamental right, there would be nothing impermissible about the classification employed, since the class of persons with outstanding child support obligations is not suspect or quasi-suspect for equal protection purposes. Justice Stewart objected to the invocation of equal protection for precisely this reason: "The problem in this case is not one of discriminatory classifications, but of unwarranted encroachment upon a constitutionally protected freedom." Id. at 391-92 (Stewart, J., concurring in the judgment). Despite the validity of this objection, Justice Marshall's invocation of equal protection analysis aptly indicates that the state may not use its power to define marriage in a manner that excludes an identifiable class of persons from marrying.

49. The separate concurrences in the judgment by Justices Stewart and Powell appear to reflect this idea. While both Justices agreed that the Constitution imposes limits on state regulation of marriage, they also argued that many valid regulations of marriage necessarily have the effect of excluding some persons 
not run afoul of the fundamental right to marry if marriage were by nature incompatible with same-sex unions.

Thus, under Zablocki it is necessary to ask whether marriage itself excludes same-sex couples-or whether the state arbitrarily excludes same-sex couples from marriage. The answer cannot turn on the fact that the state has built gender-based conditions into the eligibility requirements for marrying. One must look beyond the fact that same-sex couples are currently prohibited from marrying and ask whether this prohibition is reasonably connected to the broader functions and purposes of marriage as a legal relationship.

\section{B. Can Tradition Justify Exclusion?}

To many people, there is an obvious justification for excluding same-sex couples from marriage: Marriage is and always has been limited to persons of the opposite sex. That's just how marriage has traditionally been defined. No doubt, this response has a certain commonsense appeal. And it has also appealed to several courts that have considered the matter. The Minnesota Supreme Court, for example, found that marriage is by nature limited to opposite-sex couples because "marriage as a union of man and woman . . . is as old as the book of Genesis." ${ }^{50}$ Likewise, the Kentucky Court of Appeals took judicial notice of the fact that "marriage has always been considered as the union of a man and a woman."

This traditional exclusion of same-sex couples from marriage may be relevant to the constitutional right to marry, because the Supreme Court has on occasion stated that the existence of fundamental rights is to be determined by reference to "those liberties that are 'deeply rooted in this Nation's history and tradition." "52 Courts have therefore looked to traditional definitions of

from that legal relationship. Id. at 392 (Stewart, J., concurring in the judgment) (noting that states may legitimately prohibit marriage between siblings, persons with venereal disease, or persons who are already married); id. at 399 (Powell, J., concurring in the judgment) (noting that state regulation of marriage includes bans on incest, bigamy, and homosexuality, as well as fault requirements for divorce).

50. Baker v. Nelson, 191 N.W.2d 185, 186 (Minn. 1971), appeal dismissed, 409 U.S. 810 (1972). One might quarrel with the accuracy of this claim, however. At best, Genesis appears to be authority for the institution of marriage as a union of one man and several women. See Genesis 29:1-30:24 (narrating story of Jacob's marriage to more than one woman at same time); cf. 1 Kings 11:3 (stating that Solomon had 700 wives, in addition to 300 concubines). The history of marriage is neither as monolithic nor as monogamous as the Baker court suggests. See generally William N. Eskridge, Jr., A History of Same-Sex Marriage, 79 VA. L. REV. 1419, 1435-84 (1993) (reviewing history of same-sex unions throughout Western and nonWestern history). If one ignores several significant nineteenth-century religious movements, however, the Minnesota court's description probably holds true for most of the history of the United States. Yet, as the present Section of this Note argues, the exclusion of same-sex couples from marriage throughout American history is simply irrelevant to whether the fundamental right to marry extends to such couples. Eskridge argues that his historical survey of marriage undermines essentialist arguments against same-sex marriage. Id. at 1485. This Note has a different goal: to provide a holistic reading of American marriage law that is equally compatible with same-sex and opposite-sex marriage.

51. Jones v. Hallahan, 501 S.W.2d 588, 589 (Ky. 1973).

52. Bowers v. Hardwick, 478 U.S. 186, 192 (1986) (quoting Moore v. City of East Cleveland, 431 U.S. 494,503 (1977) (plurality opinion)). 
marriage to limit the scope of the fundamental right to marry. The Hawaii Supreme Court, for example, rejected a fundamental rights challenge to the prohibition of same-sex marriage because the court did "not believe that a right to same-sex marriage is . . . rooted in the traditions and collective conscience of our people." ${ }^{253}$

Unfortunately, the Hawaii court's fundamental rights approach simply assumes what should be the result of its inquiry. That is, it assumes that the "right to same-sex marriage" must stand on its own feet because it is not encompassed by the well-established right to marriage simpliciter. The plaintiffs' claim, however, was that the right to marry-which is undoubtedly deeply rooted in our nation's history and tradition-extends to same-sex couples, too. In other words, they claimed the same right to marry as everyone else, not a special right to marry reserved for same-sex couples. Consider the analogy to the Lovings' fundamental rights challenge to Virginia's antimiscegenation law. The Lovings claimed the right to marry, pure and simple. But what if the Court had interpreted this as a claim to a "right to mixed-race marriage" and had then inquired into the pedigree of that narrowly defined right? The result could not have been the same. ${ }^{54}$ This is simply one manifestation of a ubiquitous feature of legal reasoning: The answer to any question usually depends on the level of generality at which the issue is framed. Should the issue be framed in terms of a (more general) fundamental right to marry or in terms of a (more specific) fundamental right to marry someone of the same sex?

Justice Scalia has suggested that there is an easy way to select the correct level of generality at which to frame such issues, at least when constitutionally protected fundamental rights are at stake. On his proposal, one should always "refer to the most specific level at which a relevant tradition protecting, or denying protection to, the asserted right can be identified," because this provides a bright-line rule for delimiting the right and thereby forestalls arbitrary judicial decisionmaking. ${ }^{55}$ And at least one same-sex marriage case has expressly adopted this "most specific level" approach in choosing to frame the issue in terms of a "right [of] persons of the same sex to marry one another." $\$ 56$

53. Baehr v. Lewin, 852 P.2d 44, 57 (Haw. 1993) (rejecting plaintiffs' fundamental rights claim to same-sex marriage under federal and state constitutions). This ruling is especially significant because the Hawaii court did rule in favor of the plaintiffs' equal protection challenge to the same marital prohibition-the only American tribunal to have issued this type of favorable ruling. See id. at 64,67 (finding that prohibition of same-sex marriage employs sex-based classification and is therefore subject to strict scrutiny under equal protection provisions of state constitution).

54. See supra note 42 and accompanying text.

55. Michael H. v. Gerald D., 491 U.S. 110, 127 n.6 (1989) (plurality opinion).

56. Dean v. District of Columbia, No. 90-13892, slip op. at 2-4 (D.C. Super. Ct. June 2, 1992). 
The problems with Justice Scalia's "most specific level" approach are, however, legion..$^{57}$ One serious objection is that it puts the methodological cart before the fundamental rights horse: It chooses a rule for the putative merit of its rigidity, rather than because it reflects the character of the constitutional rights in question. Moreover, the result of this methodological approach is anything but neutral: It gives the narrowest possible interpretation to fundamental rights by constitutionalizing exceptions to them. Far from cabining judicial discretion, it simply entrenches at the methodological level one Justice's narrow conception of fundamental rights. ${ }^{58}$ At the same time, the procedural gain that supposedly justifies this substantive loss is illusory: The "most specific level" standard does not provide a bright-line rule to guide judicial discretion in particular cases, because traditions do not come in tidy packages in which the "most specific level" is identifiable or obvious. Because levels of generality are relative, judicial discretion inevitably comes into play when judges label a description of a tradition the "most specific" one..$^{59}$

The "most specific level" methodology would also require overruling the fundamental rights holding of Loving v. Virginia. In Loving the Court did not redescribe the couple's fundamental right to marry at a more specific level as the right to marry someone of another race. The Court itself recently cited this example when it firmly rejected the "most specific level" methodology as inconsistent with its precedents:

It is ... tempting . . . to suppose that the Due Process Clause protects only those practices, defined at the most specific level, that were protected against government interference by other rules of law when the Fourteenth Amendment was ratified. But such a view would be inconsistent with our law. ... Marriage is mentioned nowhere in the Bill of Rights and interracial marriage was illegal in most States in the 19th century, but the Court was no doubt correct in finding it to be an aspect of liberty protected against state interference by the substantive component of the Due Process Clause in Loving $v$. Virginia. $^{60}$

57. The problems are so legion that only one other Justice concurred in the footnote in which this methodology was set forth by Justice Scalia, and two other Justices expressly dissented from that footnote even though they joined the remainder of the opinion. See Michael H., 491 U.S. at 132 (O'Connor, J., concurring in part, joined by Kennedy, J.) (refusing to join footnote 6 of Justice Scalia's opinion); see also id. at 139-40 (Brennan, J., dissenting) (rejecting "most specific level" methodology).

58. Laurence H. Tribe \& Michael C. Dorf, Levels of Generality in the Definition of Rights, $57 \mathrm{U} . \mathrm{CHI}$. L. REV. 1057, 1093-94 (1990).

59. Id. at 1090-93. This judicial discretion becomes arbitrary when the "most specific level" methodology is itself selectively applied in some cases but not in others. In Dean v. District of Columbia, No. 90-13892, slip op. at 3-4 (D.C. Super. Ct. June 2, 1992), the court expressly rejected the view that this methodology must be applied in all fundamental rights cases yet "recognize[d] that such a mode of analysis may be useful and appropriate in particular instances," including the same-sex marriage litigation that was before it. It is difficult to imagine a more naked expression of result-driven jurisprudence than this.

60. Planned Parenthood v. Casey, 112 S. Ct. 2791, 2805 (1992) (citations omitted). 
If it was wrong to recast the Lovings' claim at the "most specific level," then some justification must be given for recasting the analogous claim of same-sex couples as a more specific "right to same-sex marriage."

The choice of the level of generality at which to describe the claimed right does not have to be arbitrary. Whether the right of same-sex couples to marry is one aspect of the more general right to marry, or whether it is a distinct right that is sui generis, depends on whether there is a meaningful distinction between marriage in general and same-sex marriage in particular. The answer cannot be assumed at the beginning of the constitutional inquiry. It must instead be the result of an analysis of the legal function of marriage and its relation to the interests recognized in the constitutional jurisprudence relating to the right of privacy. The question is whether this body of law justifies distinguishing between opposite-sex and same-sex couples, or whether this distinction is no more relevant to the constitutional right to marry than is the distinction between same-race and mixed-race couples. ${ }^{61}$

\section{Procreation as the (Putative) Purpose of Marriage}

Several courts have recognized the need to go beyond pointing to the traditional exclusion of same-sex couples from marriage by giving a reason for retaining that exclusion or, more precisely, for treating "same-sex marriage" as altogether different from "marriage" as such, so that the fundamental right to marry does not encompass the right to marry someone of the same sex. In the view of these courts, same-sex couples cannot marry because the purpose of marriage is procreation-which everybody "knows" will never result from same-sex unions. In the words of one court:

[M]arriage exists as a protected legal institution primarily because of societal values associated with the propagation of the human race. Further, it is apparent that no same-sex couple offers the possibility of the birth of children by their union. Thus the refusal of the state to

61. Tradition may still be relevant to this analysis if it illuminates the historical basis for distinguishing between same-sex and opposite-sex marriages. But because history does not stand still, this inquiry must look beyond those rules that remain unchanged-such as the prohibition of same-sex marriage-and examine the shifting context in which they exist. It may be that the surrounding bodies of law have changed so drastically that the prohibition of same-sex marriage will be revealed as an unjustifiable atavistic vestige. See infra text accompanying notes 66-67. Justice Brennan made a similar point in objecting to Justice Scalia's methodology in Michael H., 491 U.S. at 140-41 (Brennan, J., dissenting). When viewed dynamically, references to tradition need not be conservative. Justice Harlan stated this point eloquently at the dawn of the modern era of judicial enforcement of the right of privacy:

[Due Process] has represented the balance which our Nation, built upon postulates of respect for the liberty of the individual, has struck between that liberty and the demands of organized society.... The balance of which I speak is the balance struck by this country, having regard to what history teaches are the traditions from which it developed as well as the traditions from which it broke. That tradition is a living thing.

Poe v. Ullman, 367 U.S. 497, 542 (1961) (Harlan, J., dissenting) (emphasis added), incorporated by reference in Griswold v. Connecticut, 381 U.S. 479, 500 (1965) (Harlan, J., concurring in judgment). 
authorize same-sex marriage results from such impossibility of reproduction . . . ${ }^{62}$

The idea that marriage "uniquely involv[es] the procreation and rearing of children within a family" 63 provides a supposed basis for drawing "a clear distinction between a marital restriction based merely upon race and one based upon the fundamental difference in sex." $" 64$

This interpretation of the purpose of legal marriage appears over and over again -at least in the same-sex marriage cases. ${ }^{65}$ But it is always asserted, never supported. As a result, a salutary attempt at justification becomes a futile exercise in ipse dixit. Yet, the resort to arbitrary (or result-driven) jurisprudence is by no means necessary. The courts' procreative account of marriage can be checked by asking whether procreation is ever treated as the unique function of marriage elsewhere in domestic relations law. If it is, then same-sex unions might well be incompatible with marriage. If, on the other hand, the legal emphasis on procreation vanishes once one leaves the sphere of cases directly involving same-sex couples, it may be fair to conclude that the courts' arguments within that sphere are nothing more than ad hoc defenses of an unjustified tradition of exclusion.

Parts III and IV of this Note undertake this inquiry. Part III argues that, outside the context of marriage applications by same-sex couples, laws governing domestic relations do not treat the ability to procreate as a precondition of marriage. The marital relationship is valued in its own right as a legal commitment between two intimately related adults, not because it is sometimes connected with procreation. Part IV arrives at the same conclusion through an examination of the broader constitutional right of privacy, of which the right to marry is one aspect. The right of privacy shields citizens from government interference in decisions relating to family generally, including the marital relationship between two adults, irrespective of any parent-child relationships those adults might also have. There is therefore no basis in the law for the assertion that the fundamental right to marry extends only to couples who are capable of biological procreation.

62. Singer v. Hara, 522 P.2d 1187, 1195 (Wash. Ct. App.), review denied, 84 Wash. 2d 1008 (1974).

63. Baker v. Nelson, 191 N.W.2d 185, 186 (Minn. 1971), appeal dismissed, 409 U.S. 810 (1972).

64. Id. at 187 (emphasis added). This distinction between mixed-race and same-sex marriages fades considerably when the procreative purpose of marriage is described in slightly different terms, as " "fundamental to the very existence and survival of the race." Id. at 186 (emphasis added) (quoting Skinner v. Oklahoma ex rel. Williamson, 316 U.S. 535, 541 (1942)). The Baker court appears not to have noticed the ironic ambiguity of defining the purpose of marriage in terms of the reproduction of "the race."

65. Courts have linked the fundamental right to marry with the potential for procreation in the following same-sex marriage cases: Adams v. Howerton, 486 F. Supp. 1119, 1123, 1125 (C.D. Cal. 1980), aff'd, 673 F.2d 1036 (9th Cir.), cert. denied, 458 U.S. 1111 (1982); Dean v. District of Columbia, No. 9013892, slip op. at 2-3 (D.C. Super. Ct. June 2, 1992); Baehr v. Lewin, 852 P.2d 44, 56 (Haw. 1993); Baker v. Nelson, 191 N.W.2d at 186-87; and Singer v. Hara, 522 P.2d at 1195. 


\section{MARRIAGE AND PROCREATION}

Any examination of the legal connection between marriage and procreation should not lose sight of the larger legal dynamic in which it is embedded: the progressive degendering of marriage. "Husband" and "wife" formerly denoted entirely distinct gender roles-always involving authority for the male and dependence for the female-with ramifications for every aspect of married life. ${ }^{66}$ Today, in contrast, these hierarchical roles have been emptied of virtually all legal significance. Much of this change took place in the 1960's and 1970's in response to the dual pressures of the modern feminist movement and the Supreme Court's application of heightened scrutiny to gender classifications. Yet these events are but the rapid culmination of a trend that began as early as the mid-1800's with the enactment of Married Women's Property Acts in the states. ${ }^{67}$

The progressive degendering of marriage has two implications for the present inquiry. First, it reveals that the mere longevity of the prohibition of same-sex marriage is a particularly weak justification for its retention, because the fundamentally gendered legal order that long sustained this prohibition no longer exists. Second, it suggests that present-day justifications for the prohibition of same-sex marriage will inevitably exaggerate the one remaining aspect of marriage that does remain gender-coded: its sometime connection with the biological act of procreation. But a procreation-centered interpretation of marriage is not supported by the state domestic relations laws examined in this Part: laws relating to divorce and annulment (Section A) and laws governing parental rights (Section B).

\section{A. The Grounds of Divorce and Annulment}

When courts have asserted that procreation is the primary purpose of marriage, same-sex couples have been ready with a simple and obvious reply: Opposite-sex couples may marry without showing that they possess either the

66. Hunter, supra note 7, at 15-16. Feminist critiques of marriage have spotlighted this power relation inhering in the traditional definition of the roles of husband and wife. For citations to some of the relevant literature, see $i d$. at $15 \mathrm{nn} .23-24$. For Hunter, one of the most significant aspects of allowing same-sex marriage would be the tendency of such marriages to undermine the residual power dynamic that still exists between men and women in many marriages, despite the achievement of legal equality. Id. at 16-17. Feminist critics who argue that same-sex marriage would merely reproduce the power inequality marking traditional marriage are, in Hunter's view, just as guilty of essentializing the nature of marriage as are the courts in the same-sex marriage cases. Id. at 18-19. But see Nancy D. Polikoff, Commentary, We Will Get What We Ask For, 79 VA. L. REv. 1535 (1993) (arguing that history of same-sex unions shows that they easily reinforce gendered and hierarchical notions of marriage).

67. See generally Richard H. Chused, Late Nineteenth Century Married Women's Property Law, 29 AM. J. LEGAL HIST. 3 (1985) (describing effect of Married Women's Property Acts); Jennifer K. Brown, Note, The Nineteenth Amendment and Women's Equality, 102 YALE L.J. 2175 (I993) (arguing that Nineteenth Amendment was intended to bring general legal equality to women, not just right to vote). 
ability or the intention to have children. ${ }^{68}$ But courts have remained unconvinced. In their eyes, the absence of a procreative requirement for opposite-sex couples simply reflects the "fact" that it would be too impractical and too intrusive to administer a procreation requirement in relation to opposite-sex couples, who, unlike same-sex couples, are presumed to be capable of procreating. ${ }^{69}$

Whether or not this reasoning is valid for the inception of a marriage, it cannot be valid for its termination through divorce or annulment, because the law has rarely shrunk from impractical or intrusive inquiries when a marriage is terminated. The legally recognized grounds for ending a marriage logically should refer to the conditions under which a marriage fails to live up to its legally recognized purposes. If a central purpose of marriage is procreation, then surely this purpose will be reflected in the law of divorce and annulment-for example, by making the inability to procreate grounds for divorce. If, on the other hand, the primary function of legal marriage is the facilitation of a committed intimate relationship between two adults, then the grounds for divorce and annulment should center on their relationship inter se, without reference to their procreative capacities or accomplishments. An examination of the law of divorce, both before and after the "no-fault" revolution, bears out the latter rather than the former thesis. Similarly, although the law of annulment does refer to gender-specific sexual roles, it carefully avoids referring to the procreative potential of these roles.

Between 1969 and 1985, each of the fifty states adopted a no-fault provision as part of its divorce code, sometimes as the sole ground of divorce, sometimes as a supplement to fault-based grounds. ${ }^{70}$ Under the Uniform Marriage and Divorce Act (UMDA), which has been influential in the spread of no-fault divorce, a court shall enter a decree of dissolution upon a finding that the marriage is "irretrievably broken" based on evidence that "there is serious marital discord adversely affecting the attitude of one or both of the parties toward the marriage."71 Under this standard, a marriage is "irretrievably broken" if it is marked by "such a conflict of personalities as

68. See, e.g., Adams v. Howerton, 486 F. Supp. 1119, 1124 (C.D. Cal. 1980), aff'd, 673 F.2d 1036 (9th Cir.), cert. denied, 458 U.S. 1111 (1982); Baker v. Nelson, 191 N.W.2d 185, 187 (Minn. 1971), appeal dismissed, 409 U.S. 810 (1972).

69. Adams, 486 F. Supp. at 1124-25; Baker, 191 N.W.2d at 187 . Such intrusiveness might also violate the right of privacy under Griswold v. Connecticut, 381 U.S. 479 (1965). See Adams, 486 F. Supp. at 1125; Baker, 191 N.W.2d at 187.

70. See Legislative Notes, 11 Fam. L. Rep. (BNA) 1274 (Apr. 9, 1985).

71. UNIF. MARRIAGE AND DIVORCE ACT $\$ 302$ (a)(2)(ii), 9A U.L.A. 181 (1973); see also CAL. Civ. CODE $\$ 4506(1)$ (West 1983) (allowing dissolution of marriage on grounds of "[i]rreconcilable differences, which have caused the irremediable breakdown of the marriage"). An alternative criterion of irretrievable breakdown under the UMDA is that the parties have lived apart for more than 180 days. UNIF. MARRIAGE AND DIVORCE ACT $\$ 302(a)(2)(i)$ (1973). In some state dissolution statutes, living separately for a period of time may be the only no-fault provision. See, e.g., N.Y. DoM. ReL. LaW \$ 170(5)-(6) (McKinney 1988). 
to destroy the legitimate ends of matrimony."72 Thus, like other no-fault divorce statutes, the UMDA expressly treats the relationship between the spouses themselves as the sole criterion of a viable marriage.

These broad provisions leave substantial room for judicial discretion in determining whether a relationship between two spouses actually suffers from irretrievable breakdown or irreconcilable differences. ${ }^{73}$ Yet this discretion does not extend to taking the existence or nonexistence of offspring into account. The UMDA, like other statutes, "intentionally makes no distinction between childless marriages and those with minor children. If the parties establish that their marriage has broken down irretrievably, the court is not authorized to make a contrary finding because of the impact of a dissolution of the marriage upon the minor children." ${ }^{74}$ Thus, the procreative achievements of a couple are irrelevant to whether a marriage has "broken down" and should be dissolved..$^{75}$ The measure of a functioning marriage is, quite simply, whether the spouses get along with each other, or could if they tried.

The arcane conceptual system of fault-based divorce, which still exists in many jurisdictions as an alternative to no-fault, only strengthens this conclusion. New York, for example, continues to recognize four fault-based grounds for divorce: cruel and inhuman treatment of the complaining spouse, abandonment for at least a year, confinement in prison during the marriage for three consecutive years, and voluntary commission of an act of adultery. ${ }^{76}$ The first three of these grounds plainly have to do either with the quality of the spouses' shared life (cruel and unusual treatment) or with its very existence (abandonment, imprisonment). The significance of adultery is more ambiguous, however, for while it seems akin to cruel and unusual treatment, it also has the potential to result in offspring outside of the marital relationship and might thereby relate to the alleged centrality of procreation for marriage. ${ }^{77}$

The finer points of adultery as a legal ground for divorce help resolve this ambiguity. The procreation-centered thesis is refuted by the fact that the law does not recognize many potentially procreative acts of adultery as grounds for divorce but does recognize many other acts of adultery without procreative

72. UNif. Marriage AND DivorCe ACT $\$$ 302(a)(2) cmt., 9A U.L.A. 181 (1973) (emphasis added) (quoting Newman v. Newman, 391 P.2d 902, 903 (Okla. 1964)).

73. For example, CAL. CIV. CODE $\$ 4507$ (West 1983) glosses "irreconcilable differences" as "those grounds which are determined by the court to be substantial reasons for not continuing the marriage and which make it appear that the marriage should be dissolved."

74. UNIF. MARRIAGE AND DIVORCE ACT $\$ 305 \mathrm{cmt}$., 9A U.L.A. 212 (1973). The comment adds that this had been true under prior law as well.

75. Of course, once it has been determined that the marriage will be dissolved, ascertaining the best interests of the couple's children is an important task of the court in determining conditions for custody and support. See UNIF. MARRIAGE AND DivorCE ACT $\$ \S 309,401-10,9 A$ U.L.A. 400, 549-671 (1973).

76. N.Y. DOM. REL. LAW \$ 170(1)-(4) (McKinney 1988).

77. Stoddard writes that at common law "adultery was not the sexual betrayal of one partner by the other, but the wife's engaging in conduct capable of tainting the husband's bloodlines." Stoddard, supra note 10 , at 398 . 
potential as such grounds. Under the New York statute, for instance, adultery on the part of the defendant spouse is not a ground for fault-based divorce in three situations: when the defendant's adultery was committed through the procurement or connivance of the plaintiff (procurement); when the plaintiff forgave the defendant, either expressly or by cohabiting with the defendant with knowledge of the adultery (condonation); or when the plaintiff, too, is guilty of such adultery (recrimination) ${ }^{78}$ Each of these defenses refers to conduct by the plaintiff and thus relates to whether the defendant's adultery has impaired the intimate relationship between the two spouses. In the case of condonation, the harm is repaired by forgiveness; in the case of recrimination, the defendant's adultery is not the sole cause of marital discord, since the plaintiff is equally culpable; and in the case of procurement, either or both of these descriptions might hold true. None of these defenses has anything to do with the potential for procreation or its absence. ${ }^{79}$ Adultery is not grounds for divorce because it threatens illegitimate procreation. Rather, as with extreme cruelty, it is the wrong that adultery inflicts on the innocent spouse that justifies terminating the marriage. ${ }^{80}$

An expansion of the definition of adultery beyond what the procreation theory would predict confirms this view. Adultery as a ground for divorce may include not only male-female sexual intercourse, but also "deviate sexual intercourse," including oral and anal "sodomy." adultery includes sexual relations between a spouse and another person of the same sex. ${ }^{82}$ In other words, the adultery divorce doctrine equates nonprocreative sexual activity with potentially procreative activity, and the allegedly central connection between marriage and procreation is nowhere in evidence. The conclusion is clear: Adultery is grounds for divorce, not because of any connection it may have with procreation, but because it interferes with and undermines the intimate commitment of the married couple.

Like the law of divorce, the law of annulment draws a sharp line between sexual activity as such and the ability to procreate. The former may be

78. N.Y. DOM. REL. LAW $\S 171$ (McKinney 1988). (A statute of limitations also applies. $\$ 171(3)$.) For a nineteenth-century discussion of condonation and recrimination, see Horne v. Horne, 72 N.C. 530 (1875).

79. Cf. Sayles v. Sayles, 80 N.E.2d 21, 23 (Mass. 1948) (holding that birth of child is not essential element of aduitery as grounds for divorce).

80. Note, however, that under a fault-based regime an unhappy couple may be denied a divorce and thus the permission to remarry. See, e.g., Horne v. Horne, 72 N.C. at 533 (dismissing divorce petition with conclusion "that both husband and wife are two miserable wretches, and the case is too disgusting to be longer entertained by the Court").

81. N.Y. DOM. REL. LAW $\$ 170$ (4) (McKinney 1988) (incorporating the definition of deviate sexual intercourse in N.Y. PENAL LAW $\$ \$ 130.00(2), 130.20(2)$ ). But see W. v. W., 226 A.2d 860, 862 (N.J. Super. Ct. Ch. Div. 1967) (holding that adultery, as ground for divorce, does not encompass sexual conduct other than [genital] intercourse).

82. See, e.g., Patin v. Patin, 371 So. $2 \mathrm{~d} 682$ (Fla. Dist. Ct. App. 1979); Owens v. Owens, 274 S.E.2d 484 (Ga. 1981); M.V.R. v. T.M.R, 454 N.Y.S.2d 779 (Sup. Ct. 1982); R.G.M. v. D.E.M., 410 S.E.2d 564 (S.C. 1991). 
essential to marriage, but the latter is not. The inability to engage in sexual intercourse is grounds for an annulment in many jurisdictions. ${ }^{83}$ But the cases carefully distinguish between impotence, or the inability to enter into sexual relations, and sterility, or the inability to procreate. As one nineteenth-century decision made clear, we would have to revise our conception of marriage radically if the ability to procreate were considered so essential for entering the marital state that its absence would be grounds for annulment:

It is a fact well known to medical science, and familiar in our common experience, that every woman passes through a climacteric period ... after which she is incapable of conception, and yet it has never been suggested that a woman who has undergone this experience is incapable of entering the marriage state . . . It seems to us clear, therefore, that it cannot be held, as a matter of law, that the possession of the organs necessary to conception are essential to entrance to the marriage state, so long as there is no impediment to the indulgence of the passions incident to that state. ${ }^{84}$

Here the sine qua non of marriage turns out to be sex (or "the indulgence of the passions"), not procreation.

Yet, although sexual activity in marriage need not have any connection with procreation, courts continue to treat such activity as if it required two distinct gender roles, one male, the other female. This fixation on gender-coded sexual roles reveals itself starkly in cases concerning the marriageability of transsexuals. ${ }^{85}$ In a leading English case, Corbett $v$. Corbett, ${ }^{86}$ the court held that a male-to-female transsexual could not enter into a valid marriage with a man because (the court believed) no course of sex-change therapy could "reproduce a person who is naturally capable of performing the essential role of a woman in marriage." 87 While other cases have rejected Corbett's result, they have not rejected its emphasis on gender-coded sexual roles. In a carefully reasoned New Jersey opinion, for example, the court could see no reason why the state should not recognize the results of a surgical sex-change for the purposes of marriage-as long as "the postoperative transsexual is ...

83. See David B. Perlmutter, Annotation, Incapacity for Sexual Intercourse as Ground for Annulment, 52 A.L.R.3d 589, 596-98 \& n.42 (1973).

84. Wendel v. Wendel, 52 N.Y.S. 72, 74 (App. Div. 1898). Note, however, that an annulment may be obtained for fraud, and that refusal to engage in intercourse without contraception may therefore be grounds for annulment if the refusing party expressly or impliedly indicated an intention to have children. There are several New York cases from the 1940's that construe the act of marriage itself as an implied expression of an intention to have children, so that a concealed intention not to procreate is such a fraud. See, e.g., Lembo v. Lembo, 86 N.Y.S.2d 206 (Sup. Ct. 1949). These cases appear to be exceptional, however.

85. For purposes of this discussion, a transsexual is defined as a person who has changed sexes by altering his or her physical sexual attributes through surgical, hormonal, and behavioral therapies.

86. [1970] 3 All E.R. 33 (P. 1970).

87. Id. at 48 . In the view of the court, one's gender at birth could not be altered even by the natural development of the organs of the opposite sex. Id. at 47 . 
possessed of the full capacity to function sexually as a male or female, as the case may be." same sex could not marry. ${ }^{89}$ But it also adopted the approach of earlier annulment cases and focused not on in-born characteristics or the ability to procreate, but on the ability to engage in sexual intercourse:

[F]or purposes of marriage under the circumstances of this case, it is the sexual capacity of the individual which must be scrutinized. Sexual capacity or sexuality in this frame of reference requires the coalescence of both the physical ability and the psychological and emotional orientation to engage in sexual intercourse as either a male or a female. ${ }^{90}$

Despite its laudable treatment of this particular transsexual, the New Jersey court still remains fixated on sex/gender insofar as it fetishizes the ability to engage in opposite-sex intercourse "as either a male or a female." The cases concerning transsexuals reveal that the differences in gender that are supposedly so essential for marriage are nothing more than different positions in a hypothetical sex act-even when it has no connection to procreation. Thus, if gender-based access requirements for marriage serve any purpose, it is only the suspect one of maintaining gender-based sexual and social roles. ${ }^{91}$ But, to paraphrase Loving, the fundamental right to marry may not be denied on "so unsupportable a basis" as the en-gendering of distinct sexes. ${ }^{92}$

\section{B. Marriage and Co-Parenting}

The ability to procreate has never been an essential prerequisite for marriage-except when courts try to justify the prohibition of same-sex marriage. Nonetheless, there is an obvious and important connection between marriage and having children: Marriage is the culturally and legally favored

88. M.T. v. J.T., 355 A.2d 204, 210 (N.J. Super. Ct. App. Div.) (emphasis added), certification denied, 364 A.2d 1076 (N.J. 1976).

89. Id. at 207-08 (citing Singer v. Hara, 522 P.2d 1187 (Wash. Ct. App. 1974), Jones v. Hallahan, 501 S.W.2d 588 (Ky. 1973), and Baker v. Nelson, 191 N.W.2d 185 (Minn. 1971)).

90. Id. at 209 .

91. This Note's fundamental rights analysis intersects at this point with an equal protection analysis based on the use of gender classifications. See supra note 8 .

92. See Loving v. Virginia, 388 U.S. 1, 12 (1967) (holding that fundamental right to marry may not be infringed on "so unsupportable a basis" as reproduction of distinct races). 
setting in which to bring children into the world. ${ }^{93}$ This connection is entirely consistent with the idea that the primary function of marriage is to provide a legal basis upon which two adults can structure a lasting committed relationship. Children benefit enormously from a stable family setting, ${ }^{94}$ and marriage facilitates such familial stability by allowing two intimately related adults to make a long-term commitment to each other. Undoubtedly, many opposite-sex couples decide to marry precisely because they want to provide this kind of stable family setting for their children. Just as undoubtedly, many same-sex couples also want to provide the same stable family setting for their children.

In the same-sex marriage cases, however, the courts seem to regard it as obvious that "no same-sex couple offers the possibility of the birth of children by their union." There is a sense in which this is true. Because an egg from a female and sperm from a male are required for reproduction, two persons of the same sex cannot be the biological parents of the same child. ${ }^{96}$ But an exclusive focus on biology is too narrow. For a realistic picture of parent-child relationships, biological parenthood must be supplemented by at least two other categories: legal parenthood and functional parenthood. ${ }^{97}$ An adult who is legally recognized as the parent of a child might not be her biological parent; adoption is a paradigm for the divergence of biological and legal parenthood. Similarly, an adult who fulfills the functional role of a parent by providing love, care, companionship, and discipline for a child might be neither the child's biological parent nor her legal parent; stepparents, for example, frequently function as parents, despite the fact that they are "strangers" to their spouses' children, both biologically and legally. In the reality of family life,

93. The disabilities under which "illegitimate" children long suffered provide dramatic legal evidence of the favored status of marriage as a locus for childbearing. These disabilities have been understood as condemnations-not of the child, but of "irresponsible liaisons beyond the bonds of marriage." Weber $v$. Aetna Casualty \& Surety Co., 406 U.S. 164, 175 (1972). In light of the unfairness of penalizing children for the acts of their parents, classifications based on legitimacy are now subject to heightened scrutiny under the Equal Protection Clause. Pickett v. Brown, 462 U.S. 1, 8 (1983). Note, however, that the primary effect of a policy that disfavors childbearing out of wedlock is not so much to promote procreation in marriage as to discourage procreation outside of marriage.

94. See generally JOSEPH GOLdSTEIN ET AL., BEYOND THE BEST INTERESTS OF THE CHILD 3-28 (1973).

95. Singer v. Hara, 522 P.2d 1187, 1195 (Wash. Ct. App.), review denied, 84 Wash. 2d 1008 (1974).

96. This is true even when modern reproductive technologies are used. For an overview of the basic scientific facts of reproduction-aiding technologies, see Lawrence J. Kaplan \& Carolyn M. Kaplan, Natural Reproduction and Reproduction-Aiding Technologies, in THE ETHICS OF REPRODUCTIVE TECHNOLOGY 15 (Kenneth D. Alpern ed., 1992).

97. For an excellent overview, see Nancy D. Polikoff, This Child Does Have Two Mothers, 78 GEO. L.J. 459, 461-82 (1990). Polikoff argues that the child's interests would be best served if the law were to recognize the complex reality of family life and expand the legal definition of "parent" to include all adults who play the functional role of parents in the child's life; in many cases, the child might have more than two parents. At the same time, Polikoff recommends retaining a strict distinction between this expanded class of parents, who would possess all parental rights and responsibilities, and nonparents, who would possess none. See id. at 471-73. 
these three types of parenthood can overlap, intersect, and conflict with each other in innumerable ways.

These crisscrossing parental statuses can be found among same-sex couples as well. An individual involved in a same-sex relationship may be a biological parent (perhaps, but not necessarily, as a result of a previous marriage to someone of the opposite sex), and the same-sex partner of this biological parent may serve as the functional second parent to a child raised within the context of their relationship. In other cases, neither same-sex partner may be a biological parent, but one may be a legal parent by virtue of adoption, and both may be functional parents. In still other cases, adoption may allow both same-sex partners to become the legal and functional parents of the same children. ${ }^{98} \mathrm{~A}$ narrow focus on the biological act of procreation obscures this simple fact: Many same-sex couples engage in child-rearing together. ${ }^{99}$

A narrow focus on biological parenthood also obscures the role marriage plays in this constellation. Same-sex marriage cases treat the possibility of joint parenthood as a precondition of marriage. In the law, however, this order of priority is frequently reversed: Being married is actually a precondition of joint parenthood. Marriage sometimes preempts biology for the purposes of determining who a child's legal parents are. A widely known case relating to this tradition is Michael H. v. Gerald D. ${ }^{100}$ in which the Supreme Court upheld a California statute that created an irrebuttable presumption that a child born to a married woman living with her husband is also the child of the mother's husband. The California courts had construed this presumption as a substantive rule of law favoring the familial relationship of legally married spouses: "given a certain relationship between the husband and wife, the husband is to be held responsible for the child, and ... the integrity of the family unit should not be impugned." 101

Michael H., who offered evidence showing a $98.07 \%$ probability that he was the biological father of the child involved in the case, argued that a constitutionally protected liberty interest in his parental relationship had been infringed by this state policy of favoring the integrity of the family. The Supreme Court disagreed. The mother's marriage was crucial for distinguishing the case from earlier ones in which the Court had held that a biological father

98. See infra notes 109-13 and accompanying text (discussing same-sex second-parent adoption).

99. For overviews of the legal issues surrounding child custody and adoption by parents involved in same-sex relationships, see LESBIANS, GAY MEN, AND THE LAW, supra note 10, at 481-536, and NAN HUNTER ET AL., THE RiGHTS OF LESBIANS AND GAY MEN 98-117 (3d ed. 1992).

100. 491 U.S. 110 (1989). The fundamental rights methodology advocated by Justice Scalia in Michael $H$. is discussed supra notes 55-61 and accompanying text. The substantive outcome of the case did not depend on this methodology; indeed, two other Justices joined Justice Scalia's plurality opinion in its entirety-except for the methodological footnote. See id. at 132 (O'Connor, J., concurring in part).

101. Id. at 119-20 (plurality opinion) (quoting Michael H. v. Gerald D., 191 Cal. App. 3d 995, 1005 (1987) (quoting Vincent B. v. Joan R., 126 Cal. App. 3d 619, 623 (1981))). Note, however, that California would allow the husband or the wife to present evidence showing that the husband was not the father of the child; under these circumstances, the presumption was not irrebuttable. Id. at 115. 
does have a liberty interest in his parental relationship with his child: "Where ... the child is born into an extant marital family, the natural father's unique opportunity [to develop a relationship with his offspring] conflicts with the similarly unique opportunity of the husband of the marriage; and it is not unconstitutional for the State to give categorical preference to the latter."102

But not only is it constitutional to allow marital status to trump biological paternity in this way, it has also been the legal norm to do so. As Justice Scalia reminds us, the presumption of legitimacy was "a fundamental principle of the common law" that "could be rebutted only by proof that a husband was incapable of procreation or had had no access to his wife during the relevant period." 103 Even today, "the ability of a person in Michael's position to claim paternity has not been generally acknowledged." 104

Indeed, contemporary statutes have actually expanded the presumption of paternity beyond the scope of the common-law rule to cover cases in which the husband is incapable of procreation. The virtually unanimous rule of law is that a husband who consents to the artificial insemination of his wife with sperm from a third-party donor is treated as the legal father of any resulting child. ${ }^{105}$ In this context, the law combines with modern reproductive technology to render husband and wife joint legal parents, even when it is physically impossible, because of the husband's sterility, for both to be the biological parents of a child. Under these circumstances, marriage becomes the precondition for procreation, not vice versa.

Biologically speaking, the situation of opposite-sex couples in these circumstances is virtually identical to that of same-sex couples. In neither case can both partners be the biological parents of the same child. It is therefore easy to imagine a legal rule, analogous to that applied to married opposite-sex couples, which would bestow legal parenthood upon spouses in a same-sex marriage when one of them is the biological parent of a child. Just such a rule was applied in Karin T. v. Michael $T^{106}$ Karin and Michael appeared to be a typical married couple with two children. When they separated and Karin sought a child support order, however, Michael denied that he was the fatherthe children had been conceived via artificial insemination, and Michael (a.k.a. Marlene) was, biologically, a woman. Since the court did treat

102. Id. at 129 (plurality opinion) (distinguishing Lehr v. Robertson, 463 U.S. 248 (1983)).

103. Id. at 124 (plurality opinion).

104. Id. at 125 (plurality opinion).

105. Michael J. Yaworsky, Annotation, Rights and Obligations Resulting from Human Artificial Insemination, 83 A.L.R.4th 295, 301 (1991). This rule has even been applied to a case in which a married woman was artificially inseminated with the sperm of a man who was not her husband in order to bear a child pursuant to a surrogacy contract with a third man. Thus, the husband was neither the biological parent nor the intended functional parent of the child. The court nonetheless held that the husband was the legal father and that his consent, rather than that of the biological father, had to be obtained before the third man (who had contracted for the surrogacy and was the would-be functional father) could adopt the child. In re Adoption of Reams, 557 N.E.2d 159, 163-64 (Ohio Ct. App. 1989).

106. 484 N.Y.S.2d 780 (Fam. Ct. 1985). 
Michael/Marlene as a woman for the purposes of the case, ${ }^{107}$ the marriage between this same-sex couple had never been valid. Yet the court could not ignore the fact that Michael/Marlene was, in a very real sense, the second parent of her former "spouse's" child:

The actions of this respondent [Michael/Marlene] ... certainly brought forth these offspring as if done biologically. The contract and the equitable estoppel which prevail in this case prevent the respondent from asserting her lack of responsibility by reason of lack of parenthood. This Court finds that ... respondent is indeed a "parent" to whom such responsibility attaches. ${ }^{108}$

Fortunately, legal recognition of this type of dual-mother-or dualfather-arrangement has not been limited to cases in which the partnership between the parents has dissolved. An increasing number of jurisdictions now allow second-parent adoption by the same-sex partner of a child's biological or adoptive parent. ${ }^{109}$ In a representative District of Columbia case, ${ }^{110}$ each of two women partners was already the legal parent of one child, one by birth, the other by adoption. Both the local Department of Human Services and the court found that adoptions of each child by the other partner would be in the best interests of the children, for whom the two women already functioned together as parents. The only possible bar to the adoptions emerged from a statute that appeared to mandate the termination of all parental rights of a biological parent upon adoption of his or her child by someone else, the only exception being for stepparent adoptions, i.e., cases in which the adopter is the spouse of the biological parent. ${ }^{11}$ The court overcame this statutory hurdle by finding that an adoption by a same-sex partner resembled the stepparent adoptions authorized by statute, and the non-birth mother was therefore allowed to adopt the children without extinguishing the parental rights of the birth mother. ${ }^{112}$

107. Id. at 782. The clerk who issued the marriage license had apparently not required birth certificates and had simply assumed that Michael/Marlene was the male she appeared to be. $l d$. at 781 .

108. Id. at 784 (emphasis added).

109. Courts in several jurisdictions, including Alaska, California, the District of Columbia, Massachusetts, New York, Oregon, and Vermont, have approved such same-sex second-parent adoptions. See NAN HUNTER ET AL., supra note 99, at 117 n.128; Nancy Polikoff, Lesbian Mothers, Lesbian Families, 14 N.Y.U. REV. L. \& SoC. CHANGE 907, 907 n.2 (1986). These cases are frequently uncontested, and few have reached the appellate level. Two exceptions are Adoptions of B.L.V.B. and E.L.V.B., 628 A.2d 1271 (Vt. 1993), and Adoption of Tammy, 619 N.E.2d 315 (Mass. 1993), both of which allowed second-parent adoptions by the same-sex partners of the children's natural parents.

110. Adoption of Minor (T.), No. A-269-90, 1991 WL 219598 (D.C. Super. Ct. Aug. 30, 1991).

111. D.C. CODE ANN. § 16-312(a) (1989).

112. Adoption of Minor (T.), 1991 WL 219598, at *3. An analogy with stepparent adoptions has also been drawn in Adoptions of B.L.V.B. and E.L.V.B., 628 A.2d 1271, 1276 (Vt. 1993), and in In re Adoption of Evan, 583 N.Y.S.2d 997, 1000 (Sur. Ct. 1992). Adoption of Tammy, 619 N.E.2d 315 (Mass. 1993), reached the same result without relying on the stepparent analogy. 
It is ironic, then, that these same women cannot marry each other because they are supposedly incapable of "procreating." Legally and functionally speaking, they have already done so. Same-sex second-parent adoptions allow "the children of such unions the benefits and security of a legal relationship with their de facto second parents." 113 Yet the parents themselves are denied the security of a legal relationship with each other. Note the contrast with how the law treats identically situated opposite-sex couples. Far from denying such couples the right to marry simply because they are unable to reproduce biologically, the law allows them to marry and then protects their decision to form a family by presuming that they are the joint parents of children born into their household. This legal treatment of parenthood is designed to protect the "marital family"14 regardless of whether the spouses are capable of conceiving a child together. In these cases, the potential for joint parenthood is not the precondition of marriage, but its result.

The idea that the "fundamental difference" between the sexes is relevant to marriage because marriage is centered on procreation cannot be sustained. The ability to procreate is not and never has been essential for entering into a marriage. This is reflected both in laws relating to the annulment or dissolution of marriages and in many laws relating to the parental status of married couples who are biologically infertile. The supposed "fundamental difference" between the sexes is relevant to marriage in only one way: The state prohibits same-sex marriage. But same-sex and opposite-sex couples have an identical interest in a legal means of securing their familial relationships. The constitutional right of privacy requires the state to provide this legal framework.

\section{SAME-SEX MARRIAGE AND THE RIGHT OF PRIVACY}

The right of privacy prevents the state from taking over the lives of individual citizens by making basic familial decisions for them. In the case of decisions relating to marriage, this right imposes an affirmative obligation on the state: the obligation to create a legal framework for marriage and to open it equally to adult couples regardless of gender.

The right to be free from state interference in decisions about family is logically prior to and independent of any abstract right one might have to

113. Adoptions of B.L.V.B. and E.L.V.B., 628 A.2d at 1276.

114. Michael H. v. Gerald D., 491 U.S. 110, 124 (1989) (plurality opinion) (characterizing purpose of traditional presumption of legitimacy). To be sure, there are many situations in which the integrity of the marital family should not trump the parental rights of biological parents. The parental rights of "surrogate" mothers, for example, surely deserve greater protection than those of anonymous donors of sperm for use in artificial insemination, since birth mothers must carry their children to term. The problematic character of "surrogacy" may raise higher hurdles for dual-father families than for many other couples. For a variety of viewpoints on the ethical difficulties posed by reproductive technologies, see generally the essays collected in THE ETHICS OF REPRODUCTIVE TECHNOLOGY, supra note 96. 
engage in sexual conduct. In Bowers v. Hardwick ${ }^{115}$ the Supreme Court affirmed the power of the state to prohibit sexual conduct between two persons of the same sex. But Bowers does not imply that the state may also prohibit two persons of the same sex from marrying each other. Engaging in same-sex sexual conduct might not be a fundamental right, but the right to marry is one. As a result, the state may not use its power to regulate same-sex sexual conduct in order to prohibit same-sex marriage. ${ }^{116}$

Bowers would provide a basis for upholding the prohibition of same-sex marriage only if the right to marry depended on a prior right to engage in sexual activity. But in our constitutional order, the interest in familial choice is prior to that in sexual liberty. The right of privacy, which encompasses the right to marry, concerns choices about familial relationships. Its connection with sexual conduct is merely secondary, derived from this primary concern. Bowers itself acknowledged this point: The Court's privacy precedents protect individual choices regarding "family, marriage, [and] procreation," but not, or at least not directly, choices involving "any kind of private sexual conduct between consenting adults." 117 The right of privacy is the right to have the state not make decisions about one's familial relationships-whether and whom to marry, whether and when to have children. It is such decisions, rather than choices about sexual conduct, that represent fundamental aspects of liberty in our system. Moreover, constitutional protection for decisions relating to marriage stands on the same level as, and does not depend on, the protection given to decisions relating to procreation. Privacy shields each of these familial

115. 478 U.S. 186 (1986).

116. Similarly, although the state apparently has the power to penalize parents for not satisfying their child support obligations, it may not deny them the right to marry on this basis. See Zablocki v. Redhail, 434 U.S. 374 (1978) (striking down state law preventing indigent persons from marrying if they could not meet their outstanding child support obligations).

117. Bowers, 478 U.S. at 191. Thus, Bowers depended crucially on the premise that "[n]o connection between family, marriage, or procreation on the one hand and homosexual activity on the other ha[d] been demonstrated." Id. But if such a connection were demonstrated-if, for example, same-sex couples could marry-then the right of privacy ought to provide indirect constitutional protection for at least some "homosexual activity" by virtue of the connection between such activity and familial choice. The sexual intimacy of married same-sex couples would be protected from state interference under the rationale of Griswold v. Connecticut, 381 U.S. 479 (1965), which ruled that the state may not interfere in a married couple's private sexual relations. It is the view of the author, moreover, that the right of privacy should also be extended to protect sexual relations between unmarried persons-whether they are of the same sex or of opposite sexes. This extension is necessary to protect the familial choice that is at the very core of the right of privacy. If the state could prohibit all adult sexual activity outside the bonds of matrimony, it would have the power to force individuals to choose between celibacy and marriage. Since celibacy is not a live option for most individuals, this "choice" would effectively coerce most people into marital relationships-and would in this way violate the individual's right to make fundamental choices relating to family without state coercion. Thus, the right of privacy should shield nonmarital sexual activity from state interference not so much because such sexual activity is itself intrinsically valued, but because state control over sexual activity is an inherently coercive means of imposing state-chosen identities upon individuals. For further elaboration of this connection between the right of privacy and sexual activity, see Jed Rubenfeld, The Right of Privacy, 102 HaRv. L. Rev. 737 (1989); cf. infra notes $131-46$ and accompanying text (relating Rubenfeld's privacy theory to same-sex marriage). 
choices in its own right; they are coequal aspects of the freedom to determine one's own familial status without state coercion.

That privacy protects marriage in its own right has been evident at least since Griswold v. Connecticut. ${ }^{118}$ In that case, the Court predicated its holding that the state could not interfere in the couple's private sexual relations on the fact that the couple was married; ${ }^{119}$ marriage was thus the precondition of the couple's sexual liberty, not vice versa. In addition, the holding that the state could not criminalize a married couple's use of contraceptives refutes the idea that the constitutionally protected status of marriage depends on a connection with procreation. Indeed, the Griswold Court extolled marriage as a relationship whose significance lies in the intimate commitment uniting two adults. ${ }^{120}$

The cases surrounding Roe v. Wade, ${ }^{121}$ which protect the personal decision whether to bear or beget a child, ${ }^{122}$ also demonstrate that privacy affords constitutional protection to marriage regardless of whether it is connected to procreation. The state may not use its coercive power to force one to become a parent. And the right not to procreate is no less fundamental inside of marriage than outside of it. ${ }^{123}$ Because the right not to procreate is fundamental, the state may not make procreation a precondition for marriage.

What the right of privacy insulates from the state is not sexual conduct, but decisions about whether or not to enter into a particular familial relationship. ${ }^{124}$ The state cannot, without compelling grounds, force someone to become a parent; nor can it force one not to become a parent. ${ }^{125}$ Similarly, the state cannot, without compelling grounds, prohibit one from entering into

118. 381 U.S. 479 (1965).

119. See id. at 486 . In a later case, Eisenstadt v. Baird, 405 U.S. 438 (1972), the Court struck down a state prohibition on the distribution of condoms to unmarried couples. Eisenstadt did not, however, hold that unmarried couples have the same sexual liberty as married couples. See infra notes 123-24.

120. In the words of the Court:

Marriage is a coming together for better or for worse, hopefully enduring, and intimate to the degree of being sacred. It is an association that promotes a way of life, not causes; a harmony in living, not political faiths; a bilateral loyalty, not commercial or social projects. Yet it is an association for as noble a purpose as any involved in our prior decisions.

Griswold, 381 U.S. at 486.

121. 410 U.S. 113 (1973).

122. See Planned Parenthood v. Casey, 112 S. Ct. 2791, 2810 (1992).

123. See id. at 2831 (striking down spousal notification requirement as undue burden on abortion because "[w]omen do not lose their constitutionally protected liberty when they marry"); Eisenstadt v. Baird, 405 U.S. 438, 453 (1972) ("If the right of privacy means anything, it is the right of the individual, married or single, to be free from unwarranted governmental intrusion into . . . the decision whether to bear or beget a child.").

124. Thus, in Eisenstadt v. Baird, 405 U.S. at 448, and Carey v. Population Services International, 431 U.S. 678, 695 (1977) (plurality opinion)-in which the Court struck down prohibitions on the distribution of contraceptives to unmarried persons and to minors, respectively-it was assumed that the state could directly prohibit sexual activity among these groups, but that it could not impose pregnancy and the resulting birth of an unwanted child as a penalty for violating permissible prohibitions on sexual activity.

125. See Skinner v. Oklahoma ex rel. Williamson, 316 U.S. 535, 541 (1942) (holding that mandatory sterilization statute implicates a basic civil right). 
a different type of familial relationship, a marriage uniting two adults. ${ }^{126}$ The Court itself recently summed up its privacy precedents with the conclusion "that the Constitution places limits on a State's right to interfere with a person's most basic decisions about family and parenthood." 127

Loving leaves no doubt that one of these most basic decisions about family is the choice of whom to marry. ${ }^{128}$ In cases that have directly addressed the issue, however, the courts have said that same-sex marriage and opposite-sex marriage are entirely different in kind, so that the freedom to choose one's partner without state interference cannot be extended to the same-sex context. Against the view of these courts, this Note has argued there is nothing about marriage as a legal institution that renders it any less suitable for same-sex than for opposite-sex couples. There is nothing about the legal roles of spouses that requires that they be of opposite sexes-except the naked and arbitrary demand that they be of opposite sexes. The respective genders of the potential spouses are simply irrelevant to the right to marry, and therefore the prohibition of same-sex marriage can stand only if the state provides a justification for it that will survive heightened judicial scrutiny. ${ }^{129}$

The fundamental right to marry-regardless of gender-stands squarely within the domain of the Supreme Court's privacy precedents. But what are the theoretical underpinnings for this position? Typically, the language of privacy suggests that it is a sphere into which the state may not "intru[de]" or "enter," 130 at least not without a very good reason. The paradigmatic form of such intrusion is a state-sponsored prohibition or, perhaps, an undue burden on the exercise of a fundamental right. In a sense it is also meaningful to speak of the "prohibition" of mixed-race or same-sex marriage, inasmuch as mixed-race or same-sex couples are excluded from an otherwise available legal status. Nonetheless, the language of privacy is misleading in an important sense: It evokes a Lockean/Lochnerian conception in which a realm of privacy already exists apart from the state or the law, so that protection of this privacy only requires the state not to intrude on that realm. Bearing or begetting a child may fit comfortably into this paradigm. Marrying does not. Once the prohibition of same-sex marriage is struck down, the state does not walk off

126. Because Anglo-American law has never considered a marriage to be valid unless it was entered into voluntarily (at least as a formal matter), there have apparently been no constitutional cases considering the converse of Loving and Zablocki: that the state cannot compel marriage.

127. Planned Parenthood v. Casey, $112 \mathrm{~S}$. Ct. at 2806 (emphasis added).

128. See supra notes $40-42$ and accompanying text.

129. Majoritarian "notions of morality" are not a sufficiently compelling justification to defeat this fundamental right. Although the Court has held that such notions of morality are an adequate rationale for anti-sodomy laws, this holding was based upon the prior finding that such sexual conduct is not a fundamental right. See Bowers, 478 U.S. at 196. Where fundamental rights are at issue, as with the right to marry, majoritarian moral sentiments cannot defeat them; otherwise, every fundamental right would be defeasible by simple majority vote. See Casey, $112 \mathrm{~S}$. Ct. at 2806-07.

130. See Casey, 112 S. Ct. at 2807 (quoting, respectively, Eisenstadt v. Baird, 405 U.S. 438,453 (1972) and Prince v. Massachusetts, 321 U.S. 158, 164 (1944)). 
the scene, but remains in a leading role: It must now sanction and recognize same-sex marriages. Privacy must be reconceptualized to account for one of its most central aspects, the right to marry.

Jed Rubenfeld's reading of the right of privacy provides one route to such a reconceptualization. Rubenfeld criticizes the common understanding of the right of privacy as protecting "personhood," or the individual's freedom of self-definition. ${ }^{131} \mathrm{He}$ proposes that privacy be understood not as the right of the individual to define her own identity, but as the right not to have an identity imposed upon her by the state. ${ }^{132}$ This subtle shift is important because it incorporates the state into the definition of privacy from the very beginning: Privacy exists against the state, not prior to it. From this perspective, laws appear not merely as prohibitions that prevent an individual from defining her own identity, but also and especially as productive forces that serve to impose state-favored identities upon the individual. ${ }^{133}$ Such laws "standardize" the lives of their targets by compressing them into particular, narrowly defined molds. ${ }^{134}$ They are, in a word, "totalitarian." 135

Understood as a bulwark against the totalitarian imposition of identities by the state, the right of privacy emerges directly from our constitutional commitment to democracy. Privacy prevents the state from subverting its accountability to the people by totally conditioning their very existences. ${ }^{136}$ The right of privacy exists not to protect a "pre-political" private sphere, but "because democracy must impose limits on the extent of control and direction that the state exercises over the day-to-day conduct of individual lives."137

This conception of privacy provides a fitting framework for understanding the fundamentality of the right of persons of the same sex to marry. There is nothing problematic about the fact that marriage, as a legal relationship, does not exist prior to the state, because the privacy that is protected by the Constitution is not a realm of natural right antedating political life. Privacy prohibits gender-based marriage restrictions because of the standardizing and identity-imposing force that they have upon the lives of citizens.

131. Rubenfeld, supra note 117 , at $754-55$, passim.

132. Id. at 782. Rubenfeld argues that the concept of the individual's true personal identity-whether defined by the state or by the individual herself-is in fact more repressive than liberating; hence, freedom should be understood in terms of resisting identities rather than choosing them. Id. at 781; see also id. at 770-82 (deriving outline of and support for argument from French philosopher Michel Foucault). For the reasons stated below in the text, Rubenfeld's approach to the right of privacy is enormously illuminating even if one does not entirely agree with his assessment of the idea of personal identity.

133. Id. at 782-83. For example, anti-abortion laws violate privacy not because a woman defines herself through the prohibited act of abortion, but because such laws allow the state both to impose the identity of a mother upon a woman and to occupy her entire body and existence, first as she carries the child to term, then as she raises it. $I d$. at $782,788-89$.

134. Id. at 786-87 (citing Meyer v. Nebraska, 262 U.S. 390, 40I-02 (1923) and Pierce v. Society of Sisters, 268 U.S. 510, 535 (1925)).

135. Id. at 787,805 .

136. Id. at 805 .

137. Id. at 804-05. 
Not sanctioning same-sex marriages imposes standardized identities in several ways. First, it reproduces specific gender roles by enforcing a system in which gender is always relevant to the possibility of intimate relations, and by obsessively focusing on a single type of sexual conduct in which men and women have set, stereotyped positions. ${ }^{138}$ Seen from this angle, the "fundamental difference in sex" cited in some same-sex marriage cases ${ }^{139}$ is actually produced by the very prohibition it is supposed to justify. The apparently marginal case of transsexuals reveals the totalitarian implications of the prohibition: A person who is born male may marry another male only if he allows himself to be physically, psychologically, and emotionally transformed in order to "engage in sexual intercourse as . . . a female."140

Gender-based marriage laws have a different type of productive effect on those who resist their terms, who forgo marriage rather than allow the state to take over their bodies, their psyches, and their emotional lives. These resisters will often be gays and lesbians-people who are sexually oriented toward others of the same gender. ${ }^{141}$ When such people resist stereotyped gender roles by pursuing a same-sex relationship involving meaningful intimacy, the state denies them the means for making a legally binding commitment in that relationship. In this way, the law produces and imposes another stereotyped identity: the identity of the isolated and outcast "homosexual," whose deviant sexuality is incompatible with committed familial relationships. ${ }^{142}$

The totalitarian implications of denying the right to marry are not limited, however, to the imposition of stereotyped identities based on classifications like gender and sexual orientation. Whenever the state withdraws access to marriage, it imposes an identity on those to whom the right is denied, even when, as in Zablocki, the restriction is based on a classification that is not otherwise invidious or stereotyping. ${ }^{143}$ Consider a case in which the state

138. See Hunter, supra note 7 , at 15-17; cf. Rubenfeld, supra note 117 , at $799-802$ (describing the productive effects of sodomy laws in similar terms). (1972).

139. E.g., Baker v. Nelson, 191 N.W.2d 185, 187 (Minn. 1971), appeal disnissed, 409 U.S. 810

140. M.T. v. J.T., 355 A.2d 204, 209 (N.J. Super. Ct. App. Div.), certification denied, 364 A.2d 1076 (N.J. 1976); see also supra notes 88-92 and accompanying text.

141. As the Hawaii Supreme Court has noted, a same-sex marriage need not involve gays and lesbians (i.e., "homosexual" persons), or those who are sexually attracted to members of their own sex, just as an opposite-sex marriage need not involve heterosexual persons, or those who are sexually attracted to members of the opposite sex. Baehr v. Lewin, 852 P.2d 44, 51 n.11 (Haw. 1993). But since most people want to marry partners to whom they are sexually attracted, gays and lesbians are probably more likely than heterosexuals to remain single in response to the prohibition of same-sex marriage.

142. Marc Fajer has documented the extent and significance of the common stereotype (or "preunderstanding") of lesbians and gay men as persons whose sexuality is "obsessive, and completely divorced from love, long-term relationships, and family structure." See Marc A. Fajer, Can Two Real Men Eat Quiche Together?, 46 U. MIAMI L. REV. 511, 513-14, 537-50 (1992); see also Mary A. Case, Couples and Coupling in the Public Sphere, 79 VA. L. REV. 1643 (1993) (exploring problematic status of gay couples in gay rights litigation). This stereotyped conception of gay sexuality also manifests itself in the Supreme Court's failure to detect any possible connection between "homosexual activity" and committed familial relationships such as marriage. See Bowers v. Hardwick, 478 U.S. 186, 191 (1986).

143. See supra notes $43-49$ and accompanying text. 
simply repeals all laws governing marriage, effectively eliminating it as a legal institution. Could this complete absence of state regulation and classification run afoul of the right of privacy? Yes, because it would relentlessly impose an identity upon the entire citizenry. Without marriage or a similar legal institution, every person is reduced to the status of a legal atom. Individuals lose the legal medium whereby they may join together and appear before the state and others as a couple. More importantly, without marriage couples are prevented from making a legally enforceable commitment to remain together in an intimate relationship. In a world in which the state has monopolized the power to enforce commitments, the withdrawal of that power from a particular sphere of life is a productive redeployment of state power in its own right. By eliminating the legal framework of marriage, the state produces an isolated legal subject whose capacity to embark upon committed projects with others is limited to the sphere of self-interested economic transactions-homo economicus in its purest form. Far from being an unmitigated triumph for individual freedom, this type of legal atomization is a favored tool of totalitarian regimes. ${ }^{144}$

The state can standardize the lives of its citizens by withholding law as surely as it can by promulgating law. The forced isolation produced in the absence of marriage is one example of this. Of course, this defect is not cured by moving to the opposite extreme, by making marriage compulsory. Compelled marriage takes over one's life at least as much as enforced isolation does. The central tenet of privacy is that the state may not make such a choice for the individual. It does not follow from this tenet, however, that the state must vanish from the realm of privacy altogether; in that case, marriage would also vanish as an alternative. Although privacy is a right against the state, it cannot exist without the state. ${ }^{145}$ The right of privacy is not pre-political; it

144. This is a venerable theme in political thought. Tocqueville, for example, remarked the contrast between the profusion of local attachments in democratic America and the isolating despotism of the Second Empire, which he saw as the culmination of the long trend in France toward autocratic government predicated on the atomization and homogenization of the people. See ALEXIS DE TOCQUEVILLE, THE OLD REGIME AND THE FRENCH REVOLUTION at xiii (Stuart Gilbert trans., Anchor Books 1955) (1856). A similar theme appears in George Orvell's more ominous vision of the totalitarian future, where resistance to the Party takes the form of love between two people, a love that the Party (through the Ministry of Love) must obliterate in order to assure the absolute subjugation of its populace. GEORGE ORWELL, NINETEEN EIGHTYFouR 167, 282-300 (Harcourt, Brace \& World 1949).

145. Because legal marriage cannot exist without the state, the right to marry is unlike another potential state obligation-providing abortion funding for indigent women-which the Supreme Court has held not to be implicated by the constitutional right of privacy. See Harris v. McRae, 448 U.S. 297 (1980) (upholding prohibition on use of Medicaid funds for most abortions); Maher v. Roe, 432 U.S. 464 (1977) (upholding regulation granting Medicaid benefits for childbirth but not for nontherapeutic abortions). Withholding funding is different from withholding law. The allocation of public resources is almost always a quintessentially political task requiring a high level of judicial deference. See, e.g., Bowen v. Gilliard, 483 U.S. 587, 598 (1987) (stating that Congress' plenary power to define economic entitlements requires deferential judicial review). In the Court's view, when the state denies funding it does not entirely eliminate a right, but merely leaves the would-be recipient no better off than she would have been had the state not entered the field. A different analysis would be called for if the state had monopolized the field through, e.g., socialized medicine, so that denial of public services would deny access to a right altogether. See 
arises out of our constitutional commitment to democracy. It is also not prelegal. It requires law for its realization. ${ }^{146}$

\section{CONCLUSION}

Some advocates argue that the right to same-sex marriage should be pursued as a political strategy to attain general equality for lesbian women and gay men. ${ }^{147}$ Marriage is thought to be so privileged in our society that participation in it would legitimate all same-sex relationships and the individuals who prefer them. Under the conception advanced in this Note, however, the state's recognition and regulation of marriage does not privilege this institution, but merely makes it available to those who wish to structure their relationships in accordance with it. Ideally, the benefits and burdens associated with marriage reflect the differences between the situation of a legally committed couple and the situations of couples and individuals without such legal commitment. The state's recognition of a couple's choice to undertake the mutual commitments of marriage is not the same as an endorsement of that choice. Perhaps many quarters of American society still view marriage as sacred, noble, and superhuman. ${ }^{148}$ Unfortunately, same-sex couples must reckon with the possibility that the recognition of their right to marry may lower the status of marriage as much as it raises the status of gays and lesbians.

The political implications of same-sex marriage do not concern the perceptions of others. Same-sex marriage directly implicates the citizenship of lesbians and gays themselves. Through a legal disability created by the state's denial of a legal framework for committed same-sex relationships, the state produces gay men and women as a peculiar class of second-class citizens. The

Webster v. Reprod. Health Servs., 492 U.S. 490,510 n.8 (1989).

When the state withholds law, it acts on people's lives in an entirely different way than when it withholds funding. The denial of a marriage license by the state is an absolute prohibition of the marriage, not only de facto, as in the denial of abortion funding, but also de jure. The Minnesota Supreme Court recognized this when it held that the state's statutes did "not authorize marriage between persons of the same sex and that such marriages are accordingly prohibited." Baker v. Nelson, 191 N.IV.2d 185, 186 (Minn. 1971) (emphasis added), appeal dismissed, 409 U.S. 810 (1972). Unlike the funding of abortions, the sanctioning of legal marriages is indeed monopolized by the state. The entire import of the privacy cases relating to marriage is that the state must provide a legal framework for these protected familial relationships and must not arbitrarily restrict access to them. The right to marry is the right to enter into a type of relationship that cannot exist without the state. Analogies to government-funded abortions fail to capture this essential characteristic.

146. Although Rubenfeld himself does not directly address the issue, he appears to stop short of treating privacy as a constraint on state inaction. For example, he appears to retain the state action/inaction distinction when he characterizes state-imposed standardization as the affirmative implication of actual legal prohibitions. See, e.g., Rubenfeld, supra note 117, at 783 (referring to "the interdiction by which [the law] formally expresses itself"). There is no reason, however, why Rubenfeld's approach may not be applied to certain types of state inaction as well.

147. See, e.g., Stoddard, supra note 10 , at 400.

148. Id.; see also Griswold v. Connecticut, 381 U.S. 479, 486 (1965) (describing intimacy of marriage as "sacred" and its purpose as "noble"). 
political implication of the right to marry, like the right of privacy generally, is to remove this disability, to counteract state-sponsored standardization, and thereby to prevent the state from becoming the sovereign of its people. 
